\title{
Epulatio entis
}

\author{
The Microcosm
}

Here there resounds to the mind the wondrous sweetness of the shouts of those who feast, of the banqueters calling out. ${ }^{1}$

Berthold of Moosburg's commentary on the final proposition of the Elementatio theologica ("Every partial soul, descending into becoming, descends entire; it is not the case that one part of it remains above while another part descends") recapitulated the central themes of his reconstruction of Platonic philosophy and related them directly to the life of human individuals in the realm of becoming. ${ }^{2}$ As the concluding words of his propositum indicate, he regarded Proclus' doctrine of the soul's descent as the logical culmination of the entire argument of the Elementatio:

For although something of [the human soul] always stands in the light of actual intelligence, thinking itself and its principle from which it intellectually and cognitively emanates, yet this cognition belongs to the whole soul only accidentally. Therefore, nothing of the soul is said to remain above, insofar as it is soul, but the whole descends into becoming according to the Platonists. And, thus, the intention of the element and of the entire book is manifest. ${ }^{3}$

1 Berthold of Moosburg, Expositio, Prol. 20, p. 34, 1. 966-967: Unde sonat ei mira suavitas sonus epulantium, id est sonantium epulantium. Cf. Peter Lombard, Commentaria in Psalmos, In Ps. 41:4, PL 191, 418A.

2 Proclus, Elementatio theologica, prop. 211, p. 103, 1. 1-3: Omnis partialis anima descendens in generationem tota descendit et non hoc quidem ipsius sursum manet, hoc autem descendit.

3 Berthold of Moosburg, Expositio, 211F, p. 264, 1. 246-251: Quamvis enim aliquid eius semper stet in lumine actualis intelligentiae intelligendo se ipsum et suum principium, a quo intellectualiter et cognitive emanat, tamen ista cognitio non est totius animae nisi per accidens. Ideo nihil animae dicitur sursum remanere, inquantum est anima, sed apud generationem secundum Platonicos tota descendit. Et sic etiam apparet intentio elementi et totius libri. 
The entire mechanism of invisible principles, from the thearchy through the manifold orders of entia secundum speciem, finds its end in the descent of the human ("partial") soul into becoming. ${ }^{4}$ Compressed into this brief passage were several conclusions that Berthold has reached through a reflection on the final propositions of the Elementatio. These were devoted to the nature and ranks of "total" and "partial" souls (Propositions 184-205) and, finally, to the origin and properties of the incorruptible "vehicle" or body (susceptaculum) that is always united to total and partial souls (Proposition 196) and accompanies a partial soul in its descent from being into the material body (Propositions 206-210). As Berthold saw it, once Proclus had established the properties and endurance of that spiritual body and described its descent with the partial soul into the world of becoming, he had traversed the entire order of natural providence, in which each member is identical with its operation. What is left for theology would presuppose and consummate that essential order.

For Berthold, this meant that the human soul and its incorruptible body belong to the subject matter of the Elementatio theologica, the invisible things of God within the order of natural providence. The coherence of his decision to centralise the Hermetic motif of the macrocosm and microcosm, both of which contain the four maneries of One, Intellect, Soul, and Body, depended

4 Adopting the terminology of Proclus, Berthold distinguished between three kinds of soul: (1) "whole" or heavenly souls, (2) "partial" or human souls, and (3) the images of souls (indalmata seu idola animarum; cf. Proposition 64), which are the souls of animals and plants. Their names correspond to their degree of separation from the body. According to $11 \mathrm{E}$ : (1) are participated separably (separabiliter); (2) separably and inseparably; (3) inseparably. Separability denotes the extent to which a soul has the principle of its vital motion independently of the body and, therefore, is immortal. According to ${ }_{183} \mathrm{E}$ : (1) are intellectual as a whole but not wholly (non totaliter); (2) are not intellectual as a whole nor wholly (nec se totis nec totaliter); (3) have only a trace of reason. Furthermore (1) have two parts, the intellective and vegetative, and their name reflects the fact that they are at once conjoined and separated from their bodies as a whole (se totis coniunctae et separatae); (2) have three parts, the intellective, sensitive, and vegetative, and their name reflects how they are partly conjoined and partly separated (partim coniunctae et partim separatae). The status of (1) "whole" souls is clarified at 201B: as intellectual, they receive intelligible species directly from the separate intelligences and, as vegetative, they relate directly to "universal nature" insofar as they prepare a heavenly body, through exercising their operation (per potestativam expansionem), to receive this intellectual influence seamlessly through circular motion. This completes the flow (fluxus) of form that began with the Good and proceeded through its instruments that determine its causality. In $184 \mathrm{E}$, Berthold subdivided the second group: after (1) "divine" heavenly souls, which participate a divine unity through their divine intellect, come (2a) "intellectual" souls, which are partial souls that exist in being (in ente) and ( 2 b) souls that are "receptive of change" (transmutationis susceptivae), which are partial souls that exist in becoming (in generatione) and pass from intellection to non-intellection. 
on this. According to Berthold, as was noted already, the human's unique place in the cosmos derives not from its status as an imago Dei but rather, as it were, as an imago deorum: only the human, the most composite creature, focalises all the gifts of the gods found in the macrocosm. In one sense, this is a function of the human's weakness; the active vestige of the One in the human soul is so feeble that it needs all the assistance the gods can offer. Yet this weakness becomes its glory, for as an image of all the gods, human nature mirrors the totality of the archetypical world. In this sense, the rival to human nature is not any one of the principles above it but instead the entire macrocosm as the most adequate image of God. The plenitude of the Word is unfolded in both. This is how the microcosm as the "most composite" creature is also the nexus Dei et mundi - it is at once "every creature" and the centre-point of the creation.

This vision of human nature receiving all the gifts of the gods is precisely what we find detailed in Berthold's commentary on Proposition $211,{ }^{5}$ where he forged an extraordinary synthesis of some of his most important sources (Proclus, Macrobius, the Clavis physicae, and Dietrich of Freiberg) to outline a theory of the human soul's "double descent" from God into the world of becoming. The soul's first descent is from God into its substantial union with human nature as a species, the second is from human nature to the soul's individual existence in becoming. Both, Berthold insisted, occur atemporally - their divisions are a reflection of our understanding.

In his account of the first descent, which corresponds to the constitution of human nature as a species and as the microcosm, Berthold presupposed his earlier arguments about the priority of the Good over being, the doctrine of the gods as an ordered series of primordial causes, and the ontology of ens secundum speciem. This synthesis went beyond anything we find in Dietrich, whose notion of ens secundum speciem was never applied to human nature or to a narrative of "descent". ${ }^{6}$ Here Berthold's interpretation of the exemplarist anthropology of the Clavis physicae through Dietrich's ontology will provide the decisive means for navigating these passages in the Elementatio theologica. Through his synthesis of these sources, Berthold maintained that, even now, human nature in its singularity "imitates the presiding gods" because it is constituted in being as almost (quasi) an ens secundum speciem..$^{7}$ Human

5 Berthold of Moosburg, Expositio, 211C, p. 26o, l. 90 - p. 261, l. 124.

6 The major source for this narrative structure in Berthold was Macrobius, Commentarii in Somnium Scipionis, I.11.10-I.12.18, p. 47, l. 9 - p. 51, l. 17 .

7 Berthold of Moosburg, Expositio, 211C, p. 261, l. 113-116: ubi [anima partialis] perfecte stat in humanae naturae totalitate et integritate, in qua sunt omnes homines, unus homo formatus 
nature itself, in other words, must be a member of the "world" that includes every separate being standing in the eternal enjoyment of God (in aeterna Dei fruitione).$^{8}$

Yet Berthold was careful to avoid the autotheistic implications such a position might entail. Regarding the second descent, which relates directly to the passage cited above, Berthold again followed Dietrich. Both Dominicans maintained that there is a principle (intellectus agens) within the human soul that "always stands in the light of actual intelligence". ${ }^{9}$ But as Berthold clarified, and Dietrich would concur, this does not save the soul from having to begin its return to God from the senses and with phantasms - in Proclus' terms, no part of the soul "remains above" (sursum manet). Nevertheless, as both authors recognised, their arguments about the ongoing operation of the agent intellect in the soul's ground entailed a doctrine of recollection, at least relative to the immutable reasons that cannot be derived from experience. Once again, Berthold made this more explicit than Dietrich's passing reference to the Platonic doctrine. ${ }^{10}$

Berthold's narratives of the first and second descents placed the unum animae prior to the agent intellect both in the constitution of human nature and in the individual. As we have seen, the vestigium unius is presupposed by the gods in the determination of any ens secundum speciem. In the individual, the unum animae grounds the individuated agent intellect's essential activity and ecstatically relates the person to that nature and, thus, to its perpetual imitation of "the presiding gods". The final matter for us to consider, then, will be the significance of this modification of Dietrich's anthropology for Berthold's theory of deification. In accordance with the atemporal, exemplarist view of human nature Berthold inherited from the Clavis physicae, which he advanced in his rejection of Proclus on the soul's temporal pre-existence, Berthold understood deification in terms of the return of the human individual to the state that belongs to it insofar as it is a species, and from which it is never entirely alienated (sic in ente supra loca et tempora collocatur, ubi etiam deos praesides imitatur). Ultimately, we will see that Berthold, partly inspired by Bernard of Clairvaux, understood the transitory enjoyment of such a state (intelligentia or, in other words, intellectus adeptus and the unum animae) as, so to speak, "the intellect in love" or as an operative union with the divine will.

ad imaginem et similitudinem prime boni. Et sic in ente supra loca et tempora collocatur, ubi etiam deos praesides imitatur. See also Expositio, 208E, p. 237, l. 181-187.

8 Berthold of Moosburg, Expositio, 164D, p. 33, l. 76-8o.

$9 \quad$ Dietrich of Freiberg, De visione beatifica, 1.1.1.3.6 (2) - 1.1.2.3 (3), p. 22, l. 110 - p. 25, l. 76.

10 Dietrich of Freiberg, De cognitione entium separatorum, 94.6-10, p. 258, l. 35 - p. 259, l. 67. 
Berthold's notion that the individual is related to the human species through the unum animae can also provide the necessary groundwork to begin drawing comparisons with his contemporaries like Meister Eckhart, Henry of Ekkewint, and John Tauler. ${ }^{11}$ All four Dominicans share the view that an individual participates in the same human nature that has been ennobled by the Word to the extent that a person leaves off what makes them a "this" or a "that". As they understood it, this dispossession is nothing else than the exercise of charity. All of this was entailed in Berthold's theory of the soul's double descent into becoming. If such a doctrine was "the intention of the entire book", then we can infer that, for Berthold, the purpose of the Elementatio theologica was to recall the soul to its intrinsic and vital connection to the divine providence, exercising its oblique motion by providing the rational means for the soul in the realm of becoming to make itself aware of that abiding dignity and receptive to the ecstatic operation for which it is already inherently worthy.

\section{Human Nature and the Spiritual Body}

Observe: what Proclus calls the vehicle, the Apostle calls the house or habitation. ${ }^{12}$

The doctrine of the incorruptible vehicle (susceptaculum) of the soul appears for the first time explicitly in Proposition 196 ("Every participable soul uses a first, perpetual body that has an ingenerable and incorruptible hypostasis"). ${ }^{13}$ The term "participable soul", as Berthold saw, applied generically to total and partial souls. However, at this stage of the Expositio, he applied Proclus' argument to heavenly and human souls separately, at 196D-E and 196F, respectively. When treating heavenly souls, his main sources were Dietrich of Freiberg and Averroes' De substantia orbis, and for human souls, the Clavis physicae. But Proposition 196 had clearly required that a unified account of the incorruptible vehicle be given for both kinds of soul. We will see that the disparate tendencies in Berthold's sources for Proposition 196 gave rise to ambiguities and

11 Berthold of Moosburg, Expositio, 211C, p. 261, l. 119-120: in quo descensu determinatur intra ipsam humanam naturam ad hanc singularem unitatem. See $5 \cdot 3$, below.

12 Berthold of Moosburg, Expositio, 210C, p. 249, l. 102-103: Et attende: Quod auctor vocat susceptaculum, Apostolus vocat domum seu habitaculum.

13 Proclus, Elementatio theologica, prop. 196, p. 95, 1. 1-2: Omnis anima participabilis corpore utitur primo perpetuo et habente ypostasim ingenerabilem et incorruptibilem. 
tensions in his commentary, which were not addressed before Propositions 206-210 on the incorruptible vehicle of the partial soul.

It is a principle for Proclus that from a transcendent, unparticipated monad there arises a group of immanent, participated terms (Proposition 23). The multiplicity of that participated group is in turn a function of the diversity of participants. In the case of souls proceeding from the monadic and unparticipated Soul, the differentiation of "participable souls" must occur simultaneously with bodies to participate them..$^{14}$ These participants or bodies, therefore, are required to account for a soul's distinction from the unparticipated Soul. If participable souls depend on a body for their individuation, that body must be imperishable if the participated soul's identity and immortality is to be preserved. For this reason, Proclus posited a permanent "astral" body that would guarantee the immortal soul's identity throughout the great cycle of death and rebirth, as well as a semi-permanent "pneumatic" body that is subject to divine reprobation or reward between reincarnations. ${ }^{15}$ This pneumatic vehicle, in turn, is what pervades the third body, which is entirely corruptible. For both metaphysical and theological reasons, then, Proclus held that each participable soul is eternally individuated by its own spiritual body.

Berthold's main guides while navigating Proclus' more simplified account of the single incorruptible body in Proposition 196 were Dietrich of Freiberg and the Clavis physicae. In 196F, Berthold drew upon twelve chapters in the Clavis, citing 115 lines of the text, to offer a concise presentation of Eriugenian anthropology. As Berthold presented it, the question of the nature of spiritual body in the Clavis arose from a reflection on the status of the human as imago Dei. The imago, as he read in the Clavis, includes everything in human nature that is substantial and abiding in the eternal present of God's creative Word. ${ }^{16}$ Accordingly, the imago does not include the corruptible body that is

14 This argument was made explicitly in Proclus, In Platonis Parmenidem commentaria, vol. 1, lib. I, p. 707, 1. 8-26. See also R. Chulp, Proclus. An Introduction (Cambridge: Cambridge University Press, 2012), p. 99-105.

15 The difference between astral and pneumatic bodies is only implied in Proposition 209, and was not detected by Berthold, who read this text in terms of the accretion of materiality to a single incorruptible body. For a fuller account of the doctrine in light of Proclus' other works, see E.R. Dodds, in Proclus, The Elements of Theology, p. 313-321; J. Finamore, Iamblichus and the Theory of the Vehicle of the Soul (Chico: Scholars Press, 1985), p. 85-88; J. Opsomer, “Was sind irrationale Seelen?", in M. Perkams, R.M. Piccione (eds), Proklos. Methode, Seelenlehre, Metaphysik, p. 136-166, at p. 148-151.

16 On time and eternity in Eriugena, see R. Crouse, "Predestination, Human Freedom and the Augustinian Theology of History in Eriugena's De divina praedestinatione”, in J. McEvoy, M. Dunne (eds), History and Eschatology in John Scottus Eriugena and His Time. Proceedings of the Tenth International Conference of the Society for the Promotion of Eriugenian Studies, 
extraneous to the intelligible essence of the human, but rather the spiritual body that was created in Paradise, which abides even now and will exist after the Resurrection: ${ }^{17}$

That essential body was established in Paradise; but it was yet only in reason that it and the soul were created in that general and universal human, who was made after the image of God, in whom all humans in body and soul were altogether and at once established only in possibility, and in whom they all sinned before they might have proceeded into their own substances - that is, before any could have appeared in discrete diversity in their rational soul or spiritual body. This body would have adhered to the incorruptible soul, had it not sinned. And in this body all humans will be resurrected. ${ }^{18}$

A single spiritual body belongs to "the general and universal human" in Paradise, prior to any divisions of time or place, prior even to human history and the division of the sexes, both of which are the result of the Fall. In this universal human, individuals were present only in possibility and did not yet go forth into their proper substances, into distinct souls and spiritual bodies by angelic reproduction. ${ }^{19}$ Since Adam turned towards himself rather than to

Maynooth and Dublin, August 16-20, 2000 (Leuven: Leuven University Press, 2002), p. 303311, at p. 307-309.

17 Berthold of Moosburg, Expositio, 196F, p. 127, l. 148-152: Corpus autem dico hoc corruptibile carnalis adhuc animae merito suae inoboedientiae superbiaeque diversisque calamitatibus involutae hospitium, non illud caeleste et spirituale, quod in paradiso cum animae creatum est, quale et post resurrectionem futurum erit. Cf. Expositio, 210M, p. 255, l. 321-324: Ibi enim intellectus, ibi ratio, ibi sensus, ibi seminalis vita, ibi corpus, non hoc corruptibile merito peccati superadditum, sed spirituale et caeleste ante delictum datum et in resurrectione futurum.

18 Berthold of Moosburg, Expositio, 196F, p. 128, 1. 171-178: Primum illud essentiale corpus in paradiso est conditum; sola tamen ratione et anima in ipso generali et universali homine ad imaginem Dei facto creata est, in quo omnes homines secundum corpus et animam simul et semel in sola possibilitate conditi sunt et in ipso omnes peccaverunt, priusquam in proprias substantias prodirent, id est antequam quisquam in discreta differentia in anima rationali et spirituali corpore appareret, quod corpus incorruptibili (incorruptibili] incorruptibile Clavis) animae aeternaliter adhaereret, si non peccaret; et in hoc omnes homines resurrecturisunt.

19 The Clavis omitted the more precise designation of this unrealised multiplication as a form of angelic reproduction. Cf. Eriugena, Periphyseon, lib. II, c. 582B, p. 362, l. 39753985: [...] priusquam in proprias substantias prodirent, hoc est, antequam unusquisque secundum angelicam multiplicationem in sua discreta differentia in anima rationali et spirituali corpore appareret. 
God, humanity in its fall simultaneously constitutes for itself corruptible bodies appropriate to that lower life and receives them as the tunics of skin fashioned by God (Genesis 3:21). ${ }^{20}$

Berthold undoubtedly discerned some similarities between Proclus and the Clavis on these points: the spiritual body is caused by an immobile substance (Proposition 207), while the lower body is superadded to accompany the soul's fall from being into becoming (Propositions 209-210). ${ }^{21}$ But the differences between the two authorities are even more striking. One problem concerns the numerical status of the spiritual body. In the Eriugenian perspective of the Clavis, the spiritual body as one and universal because it belongs to the "universal human". ${ }^{22}$ Individual corporeal bodies arise as bundles of properties or accidents in the realm of temporal and spatial division. ${ }^{23}$ These particular bodies are not, properly speaking, the natural bodies of their souls but rather are garments "superadded" to common humanity. ${ }^{24}$ In this sense, as John Marenbon has noted, for Eriugena there was really no question about the individuation of substance as such, since individuals are nothing but "concourses of accidents". ${ }^{25}$

Eriugena followed the consequences of this reasoning about the Fall in his account of the general Resurrection, when the diversity of fallen humanity will be restored to itself as it has always existed substantially in the divine Word. ${ }^{26}$ Material differentiation falls away entirely. In the Resurrection, souls who in Paradise existed in possibility in the universal human will be differentiated

$20 \quad$ Berthold of Moosburg, Expositio, 196F, p. 127, l. 154: ostendit animam sibi ipsi causare corpus materiale. See also Expositio, 207E, p. 229, l. 151 - p. 230, l. 19o, where Berthold cited Macrobius (In Somnium Scipionis, I.14.3).

21 Berthold of Moosburg, Expositio, 207E-F, p. 229, l. 151 - p. 231, l. 213.

22 Eriugena also called the universal human "the plenitude of humanity" (plenitudo humanitatis), following Gregory of Nyssa: Periphyseon, lib. IV, 759A-B; lib. v, 922A-C, 942B-C, 953A-B, and 957C. On Eriugena's ontology of human nature, see C. Erismann, L'Homme commun. La genèse du réalisme ontologique durant le haut Moyen Âge (Paris: Vrin, 2011), p. 149-292.

23 See the citations of the Clavis at Expositio, 74 C, p. 55, l. 206 - p. 56, l. 227, as well as Eriugena, Periphyseon, lib. v, 941D-944B.

24 Berthold of Moosburg, Expositio, 196F, p. 129, l. 202-214, citing Clavis, c. 272. Cf. Eriugena, Periphyseon, lib. IV, 801C.

25 J. Marenbon, "Eriugena, Aristotelian Logic and the Creation", in W. Otten, M. Allen (eds), Eriugena and Creation. Proceedings of the Eleventh International Conference on Eriugenian Studies, held in honor of Edouard Jeauneau, Chicago, 9-12 November 2011 (Turnhout: Brepols, 2014), p. 349-368, at p. 362-363.

26 C. Steel, "The Return of the Body into Soul. Philosophical Musings on the Resurrection", in J. McEvoy, M. Dunne (eds), History and Eschatology in John Scottus Eriugena and his Time, p. 581-6o9. 
only by their merits and virtues, but not by any vices or by any individual body. ${ }^{27}$ As Tullio Gregory observed, Eriugena was less concerned with the status of individual souls than with the unity and future integrity of humanity, ${ }^{28}$ and with situating this general return within the rhythm of nature's return to the primordial causes. ${ }^{29}$

Berthold's comments on Proposition 196 indicate that he was aware that further clarification was going to be needed on this subject, both to elucidate the doctrine of the Clavis and to show that the Elementatio theologica agrees with it. His lengthy series of citations of the Clavis in $196 \mathrm{~F}$ was bookended with two cautionary remarks:

To be sure, concerning this body that the rational soul is said to use first and that it always animates by its being, I will define nothing rashly, for it should follow that it is perpetual, since it has an ingenerable, incorruptible, and unchangeable subsistence; for just like the heavenly bodies, it does not receive any outside 'impressions', if these are thought to be 'wandering'. Let us hear, however, what Theodorus judged about this body in the Clavis. [...]

These things may be brought forward without prejudice only to be clear about what the doctors of the Church judged regarding the matter at hand. ${ }^{30}$

Berthold concluded his catena of citations by reassuring his readers that the Clavis conveyed "the most sound and catholic faith of the divine theologians, Gregory and Maximus," which itself was based on "unshakeable arguments". ${ }^{31}$

27 Eriugena, Periphyseon, lib. v, $983 \mathrm{~B}$ and $987 \mathrm{~A}-\mathrm{D}$.

28 T. Gregory, "L'eschatologie de Jean Scot", in R. Roques (ed.), Jean Scot Érigène et l'histoire de la philosophie. Laon 7-12 juillet 1975 (Paris: CNRs Éditions, 1977), p. 377-392.

29 Eriugena, Periphyseon, lib. v, 978D.

30 Berthold of Moosburg, Expositio, 196F, p. 126, l. 128 - p. 127, l. 31 and p. 13o, l. 252-3: Sane de corpore, quo anima rationalis primo uti dicitur et quod semper animat esse suo, nihil habeo temere definire, cum oporteret esse perpetuum sicut habens subsistentiam ingenerabilem et incorruptibilem et inalterabilem, cum ad instar corporis caelestis impressiones non recipiat, si esse ponitur peregrinas. Audiamus tamen, quid Theodorus in Clave sentiat de hoc corpore [...]. Haec sine praeiudicio sint adducta ad hoc solum, ut clarescat, quid circa praesentem intentionem doctores ecclesiastici senserint.

31 Berthold of Moosburg, Expositio, 196F, p. 130, l. 228-231: Sanissima namque et catholica fide credimus divinorum virorum theologi, videlicet Gregorii et Maximi, de talibus inconcussas rationes reddentium dogmate imbuti, quod Conditor humanae naturae totam simul eam creavit nec animum ante corpus nec corpus ante animam condidit. Cf. Eriugena, Periphyseon, lib. v, 884B-C. 
The tone of Berthold's cautionary remarks should be understood less as a note of disapproval than an acknowledgment that he has introduced views from reliable authorities that would be unfamiliar or possibly scandalous. He would also have realised that he had not yet explained how to relate the account of the bodies of heavenly souls in 196D-E with the incorruptible susceptaculum of human nature of 196F. Thus far, he has only given hints to the unified account that we find, for example, in his interpretation of Proposition 210 ("Every vehicle connatural to the soul always has the same shape and size, but it appears greater or smaller and in dissimilar shapes because of the additions or removals of other bodies"). ${ }^{32}$ But it would fall to Propositions 207-210 to clarify the ontology of the spiritual body of the partial soul, where, as we will now see, Berthold adapted the metaphysics of Dietrich of Freiberg that he had used relative to the incorruptible bodies of heavenly souls at 196D-E.

According to Dietrich, heavenly and earthly bodies are constituted in inverse ways. ${ }^{33}$ In the case of corruptible bodies, privation and "the indeterminate dimensions" in matter precede the form, so that the intrinsic principles of a body are not principles as such (as Berthold will say, they do not retain their nature as principles, with the properties of simplicity, spirituality, and infinity), ${ }^{34}$ but are first "individual natures" rather than "beings existing as species". The situation is otherwise for incorruptible bodies: a heavenly body is by nature intrinsically and fully ordered to its act without any privation. It is by nature first an ens secundum speciem - it is a heaven as such (caelum) before it is this heaven (hoc caelum) and an individual. As we have seen, for Dietrich, an ens secundum speciem is a being which proceeds from God "from reason" (that is, as an image) and "according to reason" (from a forma exemplaris or ratio specifica) in the divine mind. This latter ratio is a determining formal cause, giving it its definitional content, and situating it as a singular

32 Proclus, Elementatio theologica, prop. 210, p. 102, l. 1-4: Omne anime susceptaculum connaturale et scema idem semper et magnitudinem habet, maius autem et minus videtur et dissimilis scematis propter aliorum corporum appositiones et ablationes. See the citations of the Clavis physicae, c. 272-273 at Expositio, 196F, p. 129, 1. 212-214: Universaliter autem in omnibus corporibus humanis una eademque forma communis omnium intelligitur et semper in omnibus incommutabiliter constat; and 210C, p. 250, 1. 104-113: nec me existimes duo corpora naturalia in uno homine docere. Unum corpus est, quo connaturaliter et consubstantialiter animae compacto homo conficitur; illud autem materiale superadditum rectius vestimentum quoddam mutabile et corruptibile veri ac naturalis magis accipitur, quam verum corpus $[. .$.$] .$

33 Berthold of Moosburg, Expositio, 196D, p. 125, l. 89 - p. 126, l. 103. See Dietrich of Freiberg, De corporibus caelestibus quoad naturam eorum corporalem, 8.1-2, p. 384, l. 66-8o, which drew on the De substantia orbis of Averroes.

Berthold of Moosburg, Expositio, 4B, p. 104, l. 125 - p. 108, l. 242. 
entity within the universe as a per se element of its order. ${ }^{35}$ For something to be an individual ens hoc before it is an ens secundum speciem means that the universality inherent to the species is achieved only through the succession of individuals in becoming and through intellectual abstraction. However, an entity like a separate intelligence is an ens secundum speciem as such, without ever becoming an ens hoc, and serves a necessary function in the order of nature by its singular existence alone. ${ }^{36}$ The heavenly bodies are located at the boundary of these two orders: by a natural, not a temporal order, a heavenly body belongs first to the per se order of things before it is an individual or ens hoc. The heaven only becomes "this" heaven when it acquires parts posterior to the whole (partes posteriores toto) such as quantitative dimensions. ${ }^{37}$

Berthold juxtaposed the essential outlines of this argument with the human spiritual body at the beginning of $196 \mathrm{~F}$ (ad instar corporis caelestis) and went no further. By Proposition 207 ("Every vehicle of a partial soul is established from an immobile cause"), ${ }^{38}$ he began establishing the analogy directly. ${ }^{39}$ This coincided with a greater reliance on Dietrich's treatises on spiritual bodies and the Resurrection (De substantiis spiritualibus et corporibus futurae resurrectionis and De dotibus corporum gloriosorum). Finally, in Proposition 208 ("Every vehicle of a partial soul is immaterial, indivisible in its substance, and impassible"), ${ }^{40}$ he placed the human spiritual body together with the heavenly bodies as a quasi ens secundum speciem:

The vehicle itself is first the essence of body as such before it is a qualified body, and its form (that is, the partial soul) is first united to the

35 Dietrich of Freiberg, De origine rerum praedicamentalium, 5.17, p. 184, l. 117 - p. 185, l. 131; id., De visione beatifica, 1.2.1.1.3, p. 38, l. 42-80; id., De intellectu et intelligibili, II.33.5, p. 172, 1. 22-28; id., Quaestio utrum substantia spiritualis sit composita ex materia et forma, II.20, p. 333, l. 181-203. See also 4.5, above.

36 Dietrich of Freiberg, De origine rerum praedicamentalium, 3.24, p. 164, 1. 182-186: [...] ens ordinabile in genere simpliciter et per se est ens completum secundum speciem; cuius complementi ratio consistit in eo, ut sit ens per se in habendo suam suam formam substantialem ab agente per se in ordine ad finem per se intentum a natura.

37 Dietrich of Freiberg, De luce et eius origine, 10.1-13.3, p. 17, 1. 79 - p. 20, 1. 89. Cf. Berthold of Moosburg, Expositio, 209B, p. 248, 1. 49-65.

38 Proclus, Elementatio theologica, prop. 207, p. 101, 1. 1-2: Omnis partialis anime susceptaculum a causa immobili conditum est.

39 Berthold of Moosburg, Expositio, 207F, p. 231, l. 207-213: [...] susceptaculum partialis animae, cum hanc habeat rationem ad susceptaculum divinae animae, quam habet anima partialis ad divinam, sub qua ordinata est secundum substantiam [...].

40 Proclus, Elementatio theologica, prop. 208, p. 101, 1. 1-2: Omnis partialis anime susceptaculum immateriale est et indivisibile secundum substantiam et impassibile. 
essence of its vehicle, such that it is the essence of body as such before it is this body. Consequently, the union of the partial soul with its vehicle precedes whatever dimensions might be supposed to exist in it. From this it follows that not only the partial soul, but even its vehicle is indivisible in its substance. [...]

Since, therefore, the vehicle of the partial soul, which it first animates by its being, is immaterial [...] and since its union with its soul precedes dimensions - whether they are called 'indeterminate' or 'determinate' it is necessarily indivisible in its substance after the manner of the celestial bodies. In these cases, the soul is first united by nature to its subject, insofar as they are principles or beings as such, and the heaven is by nature first constituted as a being as such and is, so to speak, a being according to species; then it is determined into an individual, so that it is this heaven. ${ }^{41}$

With this notion of the spiritual body and the partial soul forming a quasi ens secundum speciem, after the manner of the heavenly bodies, Berthold has found a way of accounting for the unicity of the incorruptible susceptaculum, and thus of reconciling the Elementatio theologica with the teaching of the Fathers as interpreted in the Clavis physicae. Given his rejection of the doctrine of cyclical re-embodiment (see 5.3, below), Berthold did not see the need to posit a plurality of spiritual bodies to ensure a soul's identity over time; as we will see, the creation of individual souls occurs according to the divine will within the order of voluntary providence. In Berthold's Eriugenian modification of Proclus, the spiritual body belongs to human nature as a species. Having interpreted the Clavis itself through the ontology of Dietrich of Freiberg, Berthold could agree with the Eriugenian doctrine that, in the case of human nature,

41 Berthold of Moosburg, Expositio, 208E, p. 236, 1. 161-172 and p. 237, 1. 181-187: Ipsum susceptaculum prius est essentia corporis simpliciter quam corporis huiusmodi, et eius forma (scilicet partialis anima) prius unitur essentiae sui susceptibili, ut est essentia corporis simpliciter quam huius corporis. Et per consequens unio animae partialis cum suo susceptaculo praecedit dimensiones, quaecumque sibi fingerentur inexistere, et ex hoc non solum anima partialis, sed etiam ipsius susceptaculum est indivisibile secundum substantiam. [...] Cum igitur susceptaculum animae partialis, quod primitus animat suo esse et sit immateriale [...] et unio eius cum sua anima praecedat dimensiones - sive dicantur interminatae vel terminatae -, ipsum necessario erit indivisibile secundum substantiam ad instar corporum caelestium, in quibus prius natura unitur anima suo subiecto, inquantum sunt principia seu entia ut simpliciter et constituitur caelum prius natura ut ens simpliciter et quasi ens secundum speciem et deinde determinatur in individuum, ut sit hoc caelum. 
"neither the substances or essences or the reasons of things descend into generation, but only their passions or accidents". 42

The complete synthesis of these doctrines was achieved in Berthold's commentary on Proposition 211. Here, as was mentioned, Berthold fused the accounts of the creation of humanity in Genesis 1:26 (Faciamus hominem ad imaginem et similitudinem nostram) and in the Timaeus $41 \mathrm{a}-42 \mathrm{~b}$ (on the cooperation of the younger gods with the Demiurge in fashioning the human being). Berthold began by noting that the partial soul, because it subsists in nature, can be considered in three ways (tripliciter considerari):43 (1) in the nobler mode according to which it pre-exists in its cause, $(2)$ in itself according to existence or "essentially", or (3) according to participation, in that the cause is considered in the effect. ${ }^{44}$ The consideration of the human soul secundum causam looks to its subsistence in the hierarchy of primordial causes in light of the plurality of its intrinsic formal principles; in this perspective, the human soul is present especially secundum causam in the primordial causes of soul, intellect, and in the One. But before indicating how one ought to understand this mode of subsistence, Berthold introduces several passages from the Clavis, which alludes (alludit) to this Proclean mode: "the human is a certain intellectual notion eternally made in the divine mind". Since all that is made by God is "primordial and causal" in him, but "proceeding and caused" in time, the human substance is one, but is seen under two aspects (una dupliciter intellecta; duplex speculatio): as established in the intellectual causes and in the effects of generation. ${ }^{45}$ This dual conception was clearly at some variance with the tripartite model (cause, essence, participation), but Berthold reconciled them with the twofold descent of the soul: the first passes from the primordial causes into being, from (1) cause to (2) essence, and the second from (2) being

42 Berthold of Moosburg, Expositio, 211D, p. 262, 1. 175-7: Ex quibus aperte colligitur nec substantias seu essentias nec rationes rerum descendere in generationem, sed solum earum passiones seu accidentia. Quid autem veritatis in hoc sit circa animam partialem, plenius elucescet.

43 Berthold of Moosburg, Expositio, 211A, p. 258, 1. 13-18: omne, quod qualitercumque subsistit aut secundum causam est principaliformiter aut secundum existentiam aut secundum participationem exemplariter per 65, necessarium est ipsam partialem animam tripliciter considerari: aut ut videtur in producente praeexistens ut in causa propterea, quod omnis essentialis causa nobiliori modo praehabet in se ipsa causatum suum existens prime, quod ipsum causatum est secundario [...].

44 Berthold of Moosburg, Expositio, 211A, p. 258, l.13-31.

45 Berthold of Moosburg, Expositio, 211A, p. 259, l. 32 - p. 26o, l. 74. Cf. Honorius Augustodunensis, Clavis physicae, c. 251-252, p. 200, l. 17-22 and 2-3; c. 254, p. 202, l. 6 p. 203, l. 32. On the duplex speculatio on human nature, see W. Beierwaltes, Eriugena. Grundzüge seines Denkens (Frankfurt am Main: Klostermann, 1994), p. 82-114. 
into (3) becoming. ${ }^{46}$ In this sense, the first descent corresponds to the eternal perspective on human nature in the Clavis, and the second to its manifestations in time.

This was the Platonic doctrine that, in Berthold's view, was common to Proclus and the Clavis. The first descent of the human soul is "into being by nature and condition", and the second is "into the particular mode of being related to generation". ${ }^{47}$ We should repeat with Berthold that this dual model and the sequences of divine gifts within each descent do not imply the temporal pre-existence of the soul, but were only reflections of our mode of thinking (secundum modum nostrum intelligendi). In its first descent, the soul emanates from the Good through the primordial causes into its proper existence. The Good, through the primordial causes, "strengthens the irradiation of itself", so that the first primordial cause, power (prime virtus), bestows by its illumination "the possibility to be", and so on through being, life, intellect, and soul, until finally, "through primarily nature, [the human soul] joins to itself a spiritual and connatural body". ${ }^{4}$ This is described as the human's "singular existence" and condition, before it has gone forth into individuals. Unified with its "concreated natural vehicle", the soul in this mode "stands perfectly in the totality and integrity of human nature, in which all humans exist - one human formed after the image and likeness of the primal Good". Thus the human soul is established not "in generation", but "in being", "beyond place and time, where even now it imitates the presiding gods", ${ }^{49}$ and the spiritual body is located at the end of the partial soul's atemporal passage from its state secundum causam in the primordial causes to its existence secundum propriam existentiam or as an ens secundum speciem. Dietrich's influence can be detected clearly in

46 For a tripartite reading of the Clavis, see Expositio, 211D-E, p. 262, l. 175 - p. 263, l. 191.

47 Berthold of Moosburg, Expositio, 211C, p. 26o, l. 91-93.

48 Berthold of Moosburg, Expositio, 211C, p. 26o, l. 101 - p. 261, l. 106: Deinde secundum modum nostrum intelligendi ipsum prime bonum per donationem primordialium causarum fortificat sui ipsius irradiationem [...], per prime naturam coaptat sibi corpus spirituale et connaturale.

49 Berthold of Moosburg, Expositio, 211C, p. 26o, l. 109 - p. 261, l. 115: Sic ergo descendens anima per primordiales causas procedit per omnes per se perfectos ordines ipsarum primordialium causarum, ubi semper, plus et plus praemissis donationibus, contrahitur ad animealitatis existentiam singularem et ad unionem sui cum sibi concreato susceptaculo naturali, ubi perfecte stat in humanae naturae totalitate et integritate, in qua sunt omnes homines, unus homo formatus ad imaginem et similitudinem prime boni. Et sic in ente supra loca et tempora collocatur, ubi etiam deos praesides imitatur. The final phrase, deos praesides imitatur, came from Proclus (De malorum subsistentia, c. 7, §23, p. 202, l. 18-25); see n. 6263, below. 
Berthold's description of the human nature constituted in the Word as a "singular existence" prior to individuation.

We find the same strategy (adjusting Proclus to the Clavis using Dietrich's ontology) at work when we turn from Berthold's understanding of the unicity of the spiritual body to his account of its incorruptibility. A key feature of Eriugena's doctrine, as Berthold inherited it from the Clavis, was that the substantial spiritual body is a present condition that is "hidden" until the Resurrection. ${ }^{50}$ The Eriugenian duplex speculatio entails that the universal depth of every person corresponds to an eternal exemplar in the divine mind. Berthold evidently endorsed this theory. ${ }^{51}$ His reliance on Dietrich to explain it is clear in the following passage, where he described the nature of the spiritual body constituted spiritually in being (in ente), as distinct from its material state in becoming (in generatione):

Such spirituality is contracted by nature, that is, from the essential origin of this substance. Thus, the vehicle that the partial soul first uses and animates with its being, although it is essentially a body, is spiritual, and is so by the spirituality that abstracts from all bodily place and position, which is contracted by nature from its essential origin, according to which it depends on an immobile cause. ${ }^{52}$

For Dietrich, "spirituality contracted by nature" (when taken in its essential rather than accidental signification) applies primarily to intrinsically spiritual living substances (angels, souls) and equivocally to non-living spiritual things

50 Berthold of Moosburg, Expositio, 196F, p. 128, 1. 190-194: Cum incorruptibile perire non possit, ubi est nunc corpus incorruptibile, quod animae adhaereret, si non peccaret? Magister: In secretis naturae sinibus adhuc latet; in futuro autem saeculo apparebit, quando mortale hoc in illud mutabitur et corruptibile hoc induet incorruptionem. See also Expositio, 210M, p. 255, l. 316-320: Humana enim natura [...] non est secundum hoc consideranda, quod corporeis sensibus apparet irrationalibus animantibus similis, sed secundum hoc, quod ad imaginem Dei condita est, priusquam peccaret. In hac omne, quod Conditor primordialiter creavit, totum integrum manet. Adhuc tamen latet revelationem filiorum Dei expectans. And, similarly, Expositio, 210C, p. 25o, l. 110-114; 210D, p. 243, l. 116-120.

$5^{1} \quad$ Berthold of Moosburg, Expositio, 211A, p. 259, l. 66 - p. 26o, l. 74.

$5^{2}$ Berthold of Moosburg, Expositio, 208A, p. 232, 1. 21-25: Spiritualitas enim talis aut est contracta per naturam, ex origine scilicet essentiali talis substantiae, et sic susceptaculum, quo primitus utitur anima partialis et quod ipso esse animat, licet sit corpus per essentiam, est spirituale, et hoc spiritualitate, secundum quam abstrahit ab omni loco et situ corporali, contracta per naturam ex origine sua essentiali, secundum quam dependet causaliter ab immobilicausa. 
(spiritual places such as heaven and limbo). ${ }^{53}$ In the passage used by Berthold, Dietrich did not refer to any innate spirituality belonging to the original human body in Paradise. For Dietrich, in the case of the resurrected body, that spiritual quality is only, as it were, accidental or imbued from without (quasi ab extrinsecus indita) and is not present by nature. In other words, the spirituality of souls and resurrected bodies differ "equivocally". ${ }^{4}$ Furthermore, while certain spiritual substances are in their proper "place" essentially (such as God, the intelligences posited by the philosophers and, perhaps, Dietrich adds, heavenly souls, since these are all essential causes), others (such as angels and human souls) are in their proper place only inchoatively (inchoative) by essence and consummately (completive) or destitutely (destitutive) in their places, depending on their merits. ${ }^{55}$ Thus, in this passage at $208 \mathrm{~A}$, Berthold innovated from Dietrich, firstly, by extending the concept of innate spirituality to the soul's incorruptible body in accordance with the Elementatio and the Clavis, and, secondly, by adding an allusion to Proposition 207 ( ab immobili causa), so that the susceptaculum itself can now be said to possesses spiritual properties by nature as an ens secundum speciem, by virtue of its origin from an immobile cause in the order of being. ${ }^{56}$

Berthold had to go further to explain the relation between the spiritual and corporeal bodies when commenting on Propositions 209 and 210, where Proclus stated that the imperishable body acquires increasingly more materiality in its descent, even while it remains self-identical. According to

53 Dietrich of Freiberg, De substantiis spiritualibus et corporibus futurae resurrectionis, 36.4, p. 339, l. 15-22.

54 Dietrich of Freiberg, De substantiis spiritualibus et corporibus futurae resurrectionis, 36.8 , p. 339, l. 34-40.

55 Dietrich of Freiberg, De substantiis spiritualibus et corporibus futurae resurrectionis, 23.1-7, p. $320,1.41-$ p. 321 , l. 94.

56 This did not, however, force Berthold to understand the Resurrection simply as the return to a primordial state before the Fall. Cf. Berthold of Moosburg, Expositio, 209A, p. 240, 1. 21-31: Est et alius ordo, scilicet supernaturalis, quo gubernatur specialiter rationalis et intellectualis natura per providentiam Dei voluntariam secundum rationem meriti et praemii, et pertinet ad statum vitae felicis, quo anima cum suo susceptaculo, quod primitus animat, est in ente, ad quem statum pertinet non solum gloria animae in fruendo per contemplationem et dilectionem fonte boni, ex cuius superplenitudine ipsa anima partialis utpote supercaelestis existens illuminatur, immo superimpletur divini luminis claritate, verum etiam gloria ipsius susceptaculi, ut non solum sit spirituale spiritualitate contracta per naturam, ex origine scilicet essentiali talis substantiae, sed etiam sit et dicatur spirituale ex perfectionibus talem spiritualitatem naturaliter consequentibus, quibus ipsum susceptaculum etiam dicitur gloriosum. Although Berthold did not mention it directly, he may have endorsed the Eriugenian theory of a twofold return. See, for example, Eriugena, Periphyseon, lib. v, 908C-D, 1001A-B, and 1014B-C. 
Berthold, following Dietrich, since spirituality and corporeality are not of the same genus, a spiritual substance can "assume" or "be clothed" with corporeality without leaving off its inherent spirituality. ${ }^{57} \mathrm{In}$ an earlier passage, Berthold had already incorporated arguments from Dietrich explaining how two spiritual bodies (for Dietrich, "glorified" bodies) can be in the same place, since they do not have an intrinsic relation to that place, and to account for the way that spiritual bodies can be in the same place as corporeal bodies. ${ }^{58}$ Here in Proposition 209, however, Berthold has adapted texts in Dietrich that originally had been used relative to Christ's appearance to Thomas and the other disciples after the Resurrection in order to explain Proclus. ${ }^{59}$ The Elementatio and the Clavis led him to adapt these arguments to the present condition of the Proclean spiritual body.

So influenced was he by the Apostolic authority of the Clavis that Berthold did not regard this as a scandalous conclusion. In fact, in a most characteristic gesture, he freely drew a direct connection between Proclus' abiding and incorruptible susceptaculum and the Eriugenian reading of Paul's proclamation that we have, in the present (habemus), "an eternal house in heaven not made by hands". 60 The eternal habitation is both a present fact and a promise. We can conjecture (coniecturam capere possumus) what the quality and state of that spiritual body must be, if we compare it with the corruptible body of our everyday experience: this body is visible and is temporal, that body is not seen and is eternal, and it exceeds in perfection every visible body that we can find. Berthold followed the Clavis in search of traces or intimations of the spiritual body at the level of the invisible elements, whose subtlety and omnipresence underlie and constitute the elements of sense-experience. ${ }^{61}$ Rather than criticising Proclus' notion of an enduring and incorruptible spiritual body, he sought to bring out its agreement with the Apostle's teaching, authorised by the Clavis and understood through Dietrich's ontology.

Although Berthold would not summarise things this way, what we have witnessed so far is an undeniable subordination of Proclus' theories of the

57 Berthold of Moosburg, Expositio, 209C, p. 242, l. 91 - p. 243, l. 110.

$5^{8}$ Berthold of Moosburg, Expositio, 208B, p. 233, l. 59 - p. 234, l. 101.

59 See Berthold of Moosburg, Expositio, 209A-B, p. 241, 1. 37, 44, 6o-69, and compare with Dietrich of Freiberg, De substantiis spiritualibus et corporibus futurae resurrectionis, 31.3-4, 36.9, and 37.7.

6o Berthold of Moosburg, Expositio, 210C, p. 249, l. 83-103. Cf. 2 Corinthians 5:1: quod aedificationem ex Deo habemus, domum non manufactam, aeternam in caelis.

61 Berthold of Moosburg, Expositio, 210A, p. 247, l. 25 - p. 248, l. 47. Cf. Expositio, 129A, p. 173, l. 15 - p. 175, l. 91, and his marginalia to his manuscript of the Clavis listed in Introduction, section 2, above. 
spiritual body and re-embodiment to the Christian standpoint of the Clavis physicae. For the anthropological implications of the Expositio, however, it is perhaps even more important that we note how the balance in Berthold's synthesis shifted in the opposite direction, from the Clavis to Proclus. As we saw in his comments on Proposition 211, Berthold described the enduring condition of human nature in Proclean terms: the singular human nature constituted in the first descent "imitates the presiding gods". ${ }^{62}$ This was a reference to one of the most important passages for Berthold's interpretation of Proclus:

For each soul, when it exists above, journeys through the heavens (that is, travels the high places) and governs the entire world, beholding beings, and ascending with the presiding gods to the blissful and most perfect banquet of being, and filling those which look upon it with nectar from that place. ${ }^{63}$

Berthold alluded to this passage in his account of the astrologer as the exemplar of the nexus Dei et mundi in the Prologus, who "governs the world with the gods". ${ }^{64}$ His echo of the same text in his description of the soul's first descent (in Proposition 211) alerts us to two things. The first is that it shows how Berthold, notwithstanding his criticism of Proclus on reincarnation (see below), sought to give the doctrine an acceptable interpretation in conformity with his view of the Elementatio theologica as the consummate restoration of Plato's theorematic philosophy. Secondly, and in line with the same passage in the Prologus, the phrase "imitates the presiding gods" suggests that this abiding condition of human nature is somehow related to the highest realisation of human contemplation in this life. That is, what individuals achieve through intellectual effort and divine assistance is what human nature as a singular ens secundum speciem always does. For Berthold, this doctrine of providential cooperation with the divine, which somehow belongs always to human nature with its spiritual body, and which souls partake of only in a transitory way, was a common teaching of the greatest Platonists (Proclus, Dionysius, Macrobius,

62 Berthold of Moosburg, Expositio, 211C, p. 261, l. 115-116.

63 Proclus, De malorum subsistentia, c. 7, §23, p. 201, 1. 7 - p. 202, 1. 10: sursum quidem enim ens anima omnis meteoropori (id est alta petit) et omnem mundum dispensat, entia speculans et cum diis presidibus ad felicem et perfectissimam entis epulationem ascendens, et que in ipsam respicientia replens eo quod ibi nectare.

See 1.2, n. 66, above. 
Boethius). ${ }^{65}$ If human nature is an ens secundum speciem, then it must play an integral role within the essential order of natural providence. Its providential action, like that of the heavenly souls that always exercise the highest intellectual operation and the non-reflexive operative activity of the unum animae, cannot be intermittent. ${ }^{66}$ The difference is simply whether the soul is in generation or in being (in ente), and the latter is equivalent to the essential order of natural providence, where essence is identical to operation. In Berthold's interpretation of this passage from Proclus' De malorum subsistentia in atemporal terms, what happens when the soul ascends "to the blissful and most perfect banquet of being" is that it temporarily regains the knowledge that is always underway in its ground, which connects it with the providential operation that belongs to human nature as such. The human individual, in being harmonised with its own nature as microcosm, is harmonised with the macrocosm and the providence that is inherent to it.

The first descent of the soul arrives to the cusp of the transition from natural providence to voluntary providence, from the human species in ente to the human individual in generatione. Berthold clearly evoked the terminology of voluntary providence when he wrote that the second descent of the soul occurs when it is well-pleasing to the primarily Good with the advice of its council (ad beneplacitum prime boni de consilio sui senatus):

Within human nature [the partial soul] is determined to this singular unity, which deiform unity is specified in intellectuality, and this intellectuality is singularised to the existence of this soul, which finally is particularised by the sensible and vegetative [powers]. ${ }^{67}$

65 See the way he echoes the phrase "imitates the presiding gods" when introducing citations from these authorities at Expositio, 206C-D, 1. 81-82, 92, 117, and 141; 207A, p. 225, l. 18-21; 207B, p. 226, 1. 63 - p. 227, l. 70.

66 Berthold of Moosburg, Expositio, 197I, p. 139, 1. 220-223: In statu enim generationis potest enumeratas quinque cognitionum species exercere [opinion, science, wisdom, intellect or intelligence, the unifical], prout minus vel plus se ab his corporalibus separaverit; in statu autem entis, ubi nullus rationis discursus est, ultimae duae cognitionis species ab anima exercentur. The five modes are enumerated in Expositio, 197 G, p. 136, l. 108 - p. 138, l. 186.

67 Berthold of Moosburg, Expositio, 211C, p. 261, 1. 117-124: Existens vero in ente et totalitate naturae humanae, ut dictum est, ad beneplacitum prime boni de consilio sui senatus per descensum secundum (scilicet in generationem) in hunc mundum destinatur, in quo descensu determinatur intra ipsam humanam naturam ad hanc singularem unitatem, quae unitas deiformis specificatur in intellectualitatem et hoc intellectualitas singularizatur in hanc existentiam huius animae, quae etiam ultimo particulatur per sensuale et germinale. Et sic induit corpus materiale, quo etiam utitur secundum talis modi essendi exigentiam naturalem. See also Expositio, 24B, p. 13o, l. 189-198. 
Unlike the first descent, where each primordial cause bestowed its own effect, the action here is undertaken exclusively by God, who produces the individual soul immediately. Then soul puts on (induit) a material body, which it uses according to the natural necessities of this mode of being. The last phrase is consistent with Berthold's view of Platonic doctrine, according to which the soul is the "mover" rather than the "act" or "form" of the body. ${ }^{68}$

That God would be the immediate and exclusive agent in this process is consistent with Berthold's understanding of the relation between natural and voluntary providence. In the perspective of natural providence, the thearchy is unfolded into its necessary formal order; but from the standpoint of voluntary providence, the thearchy simply is God. The first stages of the soul's second descent as described here are somewhat mysterious, and we are left to make inferences based on passages discussed earlier in relation to the doctrine of determination in the Expositio. ${ }^{69}$ This second descent must be understood as another logical and non-temporal narrative. The movement is evidently from the more universal to the more limited. First, he began with three kinds of determinacy (determination, specification, singularisation) that correspond precisely to the terminology that defined the condition of entia secundum speciem. Such beings come forth by determination or "information", they are constituted in specific being (in esse specifico) and are "singulars". We have encountered the notion of particularisation already passing relative to the ontological status of angels and separate souls. ${ }^{70}$

Individuation, therefore, must be inchoate in the unum animae and fully realised only when the material body is finally "put on". What this seems to entail is that the soul's means of being made adequate to the condition of human nature in its abiding integrity are already latent within it, especially in its higher powers. These correspond to higher modes of life or cognition that are realised only to the extent that the soul has separated from the body. ${ }^{71}$ The goal of human life is to join itself to the higher world (applicatio eius cum mundo altiore) or to return to its higher world (redit anima ad suum saeculum

68 Berthold of Moosburg, Expositio, 207C, p. 227, l. 78 - p. 228, l. 129. Against the Peripatetics, according to Berthold, the Platonists held that the soul descends by the will of God (nutu Dei) into "an arranged body", that it does not "beg" for its intelligible species, but knows by recollecting its vision during its "natural state".

69 Cf. Berthold of Moosburg, Expositio, 201A, p. 173, 1. 36-39: colligitur omnem divinam animam habere tres partes formales intrinsecas et essentiales animae substantiam integrantes, scilicet unum, quod est divinum, et intellectum, quo specificatur, et animealitatem, qua quasi individuatur.

$70 \quad$ See 4.5 , n. 234, above.

71 Berthold of Moosburg, Expositio, 197I, p. 139, l. 221. 
altius). ${ }^{72}$ In the following section, we will look closely into the second descent of the soul by following Berthold's adaptation of Dietrich's doctrine of the agent intellect as the essential principle of the soul, as well as his understanding of how this principle relates to the essential order of natural providence and the soul's beatitude.

\section{$2 \quad$ Between Being and Becoming}

Berthold's account of the dynamic relation between the soul and its ground, in both movements of procession and return, was heavily indebted to Part II of Dietrich of Freiberg's De intellectu et intelligibili. After setting out the cosmological principles of his argument in Part I of his treatise, Dietrich then turned to describe the relationship between the agent and possible intellects (=AI, PI). Each intellect is essentially a likeness of the totality of being for, as Aristotle stated (De anima III.5, 430a14-15), the AI makes all things, while the PI becomes all things. ${ }^{73}$ Since there is an essential identity between both - the totality of being, either made or received - Dietrich described their interrelation using the all-important principle from Proposition 65 (but Dietrich cited Proposition 140 commentum) that, within an essential order, each thing shares the same essence while existing either according the mode of a cause, of the essence itself, or of participation. Thus, the PI is all things "by participation", while the AI is all things "by cause". On this point Dietrich acknowledged that he was venturing beyond the Scriptures and the articles of the faith, since the argument was compelling him to admit that a cause below God could be said to bring about the essence of a given effect. Nevertheless, he noted, having in mind Proposition $5^{6}$ of the Elementatio theologica and Proposition 1 of the Liber de causis, even the philosophers agree that whatever a secondary cause produces, the first cause does so in a more eminent way. It was safe to proceed on this assumption since the primacy of God's creative causality was not being undermined. The remainder of Part II of the treatise was devoted to deducing (deducitur) from these premises that the AI is the causal principle (principium causale) of the essence of the soul itself (II.2-II.12). Once this is established, Dietrich addressed the problems of the unicity and individuation of the intellect (II.13-II.31) before discussing the object and mode of the AI's intellection (II.32-42).

72 Berthold of Moosburg, Expositio, Expos. tit. L, p. 5o, 1. 463-468.

73 Dietrich of Freiberg, De intellectu et intelligibili, II.1.1-5, p. 146, 1. 5- p. 15o, 1. 34. 
According to Dietrich, the AI is a substance that belongs to the same class of beings that includes the separate intelligences of the Peripatetic philosophers or the "gods" of Proclus, and is identical to the hidden recess of the mind (abditum mentis) of Augustine's De Trinitate. ${ }^{74}$ These intellects are in need of no ontological supplement or accident to be what they are, that is, the ceaseless exercise of active memory, active understanding, and active will. The PI, by contrast, is nothing before it thinks, as Aristotle argued (De anima III.4, 429b3o-43Oa2). When it is actualised, it is identical to the intelligible form or species it receives from the AI. ${ }^{75}$ Dietrich understood this identity in the strongest sense: there is no PI "there" as a substance or subject before it thinks. Considered as a conceptional being (ens conceptionale inquantum huiusmodi) - a term Dietrich invented to describe the mode of being of intellectual substances when viewed in terms of their essential activities - there is something substantial about the PI's operation, because it constitutes the quiddities of things by its universal act or conception (universalis conceptio). However, in the concrete order of conceptional beings (ordo entium conceptionalium), which regards intellectual entities from the perspective of their natural being (ens naturae), the PI's actualisation by an intelligible form is accidental to it. ${ }^{76}$ With this distinction, Dietrich intended to secure the individuation of the possible intellect alongside the universality of its content. Now, since the PI is nothing before it thinks, the AI must presuppose something else that is together with it (simul) by nature before it can produce the accidental disposition that is the intelligible species. ${ }^{77}$ This something is the substance of the soul, which will receive the accidental disposition. The soul's substance is therefore in an immediate, mutual contact with the AI. Dietrich clarified that this does not mean that the AI is simply the essence of the soul, as if it were a form and the soul were its matter. Rather, they must be found together (simul) in such a way that the AI is "the essential cause" of the soul.

Dietrich held that the argument about the AI as the essential cause of the soul becomes much clearer once we accept, following Augustine, that the soul is not affected by anything beneath itself. ${ }^{78}$ In other words, the soul-body

74 See especially Dietrich of Freiberg, De visione beatifica, 1.1, p. 15, l. 10 - p. 36, l. 104; id., De intellectu et intelligibili, I.7.1-4, p. 140, l. 16 - p. 141, l. 43.

75 Dietrich of Freiberg, De intellectu et intelligibili, III.13.3, p. 187, 1. 12-17; id., De visione beatifica, 3.2.3 (4), p. 73, l. 52-64.

76 Dietrich of Freiberg, De intellectu et intelligibili, II.3.2, p. 148, 1. 80-87. On these kinds of ens conceptionale, see De intellectu et intelligibili, III.8.1-III.9.2, p. 151, l. 79 - p. 153, l. 14.

77 Dietrich of Freiberg, De intellectu et intelligibili, II.2.1-3, p. 147, 1. 50 - p. 148, 1. 76.

78 Dietrich of Freiberg, De intellectu et intelligibili, II.3.3-II.5.4, p. 148, l. 88 - p. 150, l. 34. On this doctrine in Augustine, see E. Bermon, Le cogito dans la pensée de saint Augustin (Paris: Vrin, 2001), p. 239-281. 
composite is not the subject of exterior sense-perception and the interior senses like common sense and imagination; instead, the soul alone produces (facit) and performs (exercet) both external and internal functions, while the body is only the instrument of these operations. For Augustine, this meant that the soul has a certain interiority (intraneitas) that is not conjoined to the body. Dietrich explained this as follows:

Although the soul, according to its whole essence, is conjoined to the body (because it is simple), it is not however conjoined according to every qualitative mode of its substance. For it has many diverse qualitative, substantial modes in itself, any of which imply the whole essence of the soul which, nevertheless, is one and all of them simultaneously, whether it be conjoined according to some of its modes or not conjoined according to others. Neither do these diverse modes multiply the essence, but according to each there is one simple, undivided essence beneath each. ${ }^{79}$

To explain this relation between a simple essence and its diverse qualitative substantial modes (=QSM s), Dietrich gave three examples. The first came from Augustine's argument in De Trinitate that the mind is totally present in each of its acts of memory, intellect, and will, which are distinguished only by relation. These are the QSM s of the mind. Among natural beings, we find the QSM s of genus, differentia, and species. This recalls Dietrich's theory of determination: each of these are formal intentions, which imply the entire essence of a thing while remaining distinct. As a better example, however, Dietrich purposed that we consider how the vegetative, sensitive, and rational powers of a soul are its QSM s. As Aristotle explained, each implies the total rational soul, such that the vegetative exists in the sensitive, and the sensitive exists in the rational, like the triangle exists in the quadrilateral. ${ }^{80}$ All these examples imply that QSM s are related according to a determinate order, either of coequals, in the case of imago Trinitatis (memory, intellect, will), or of prior and posterior

79 Dietrich of Freiberg, De intellectu et intelligibili, II.5.1, p. 149, 1. 3-10: Quamvis enim anima secundum totam essentiam suam coniungatur corpori, quia simplex est, non tamen est coniuncta secundum omnem modum qualitativum substantiae suae. Habet enim in se plures et diversos modos qualitativos substantiales, quorum quilibet importat totam essentiam animae, quae nihilominus una est, et tota simul est sive coniuncta secundum aliquem illorum modorum sive non coniuncta secundum alium. Nec illi diversi modi numerant essentiam, sed secundum quemlibet illorum est una simplex indivisa essentia sub quolibet illorum. 
(the soul's powers). Each QSM implies the total essence of that of which it is a mode.

Having determined that there is such an inwardness in the soul, in which the soul is entirely and essentially present, Dietrich returned to the main argument. Just as an animate thing has within itself the principle of its motion, so too the rational soul has within itself a principle of its highest mode of life, that is, to live intellectually according to the possible intellect. ${ }^{81}$ The principle of intellectual life is the AI, which necessarily is inward (intraneus) to the rational soul. This inwardness (ista intraneitas), Dietrich argued, is a "substantial identity", and implies the mutual and essential relation (respectus) of two terms. There is, then, a dynamic relationship between the AI and the substance of the soul. This, however, does not make them totally identical. Burkhard Mojsisch has rightly argued that we must interpret the preceding discussion of QSM $\mathrm{s}$ only relative to the soul's rational and vital operations, and not to say that the AI is a QSM of the soul. ${ }^{82}$ Rather, we might say that this inwardness corresponds to the soul's QSM that is the subject for the accidental disposition of the intelligible species. ${ }^{83}$ The two related terms in "this inwardness" are in one another (intra invicem) essentially (unum in alio essentialiter), and only in this way are they the same in essence (idem per essentiam). That is, the AI and the soul are two essentially related substances. In such cases, for Dietrich, Proclus' threefold modes of existence apply. The soul and the AI cannot be essentially identical in a univocal way, such that they would be one essence (una essentia), nor does the AI participate its essence from the soul. The only option remaining is that the AI relates to the soul according to cause (per causam). From this it follows that the soul is in the AI "by a more eminent and noble mode than it is in itself". 84

81 Dietrich of Freiberg, De intellectu et intelligibili, II.7.2-4, p. 15o, l. 46 - p. 151, l. 75 .

82 B. Mojsisch, Die Theorie des Intellekts bei Dietrich von Freiberg (Hamburg: Meiner, 1977), p. $5^{2-53}$.

83 Dietrich clarified (at De intellectu et intelligibili, II.6.1-2) that it does not follow from this inwardness that the soul, conjoined to the body, exercises its vital operations intellectually (intellectualiter) for, even when separated from the body, it is not essentially intellectual or an intellect. This amounts to saying that the rational soul is not an intellectual substance, because otherwise it would be an essential cause. See also De intellectu et intelligibili, II.17.1-4, p. 157, l. 38 - p. 158, 1. 67. Dietrich did not mention whether the soul or, more specifically, this intraneitas, would occupy the mode secundum essentiam between the AI (secundum causam) and the PI (secundum participationem), but it would follow from his argument.

84 See also Dietrich of Freiberg, De intellectu et intelligibili, II.8.1-II.9.4, p. 151, 1. 79 - p. 153, l. 27; id., De cognitione entium separatorum, 23.1-6, p. 186, l. 93 - p. 187, l. 110, where Dietrich observed that the agent intellect satisfies the five criteria of an essential cause. 
Although Dietrich spoke of the AI as the lowest of the order of essentially active intellects, in an important sense it is different in kind from the intelligences above it. Some essential causes (separate intelligences and heavenly souls), contain their effects in a simpler, nobler mode, but remain separate from their effects (sublunary substantial form) and share no univocal definition with them. Other essential causes "claim for themselves the conditions of their effects". This applies to human and angelic AI s. ${ }^{85}$ Such AI s have the individuating conditions of their essential effects "inchoatively", which the effects have as a "disposition". For example, a temperament exists in the soul inchoatively, in the body dispositively, and fully in the composite. According to Dietrich, the necessary and sufficient condition for individuation is the possession of parts that are after the whole (posteriores toto), which fall outside the consideration of the essence as such, but which the essence depends upon for its actuality. These parts can be quantitative, corporeal parts, such as a body's limbs and members, or qualitative parts. ${ }^{86}$ Since, at this point, Dietrich recalled his earlier discussion of QSM s, we can assume that these qualitative parts individuating the AI are something like "the sensible", "the rational", and so on. These would be inchoate in the AI by "real natural relations", which have an ambiguous status: they are really from and in the nature of a thing (realiter $a$ natura et in natura rei), like the inclination (inclinatio) of a stone to fall or of fire to rise; they exist in any AI according to its nature (in quolibet intellectu agente secundum naturam suam); and yet they are also "after the whole". ${ }^{87}$ Unlike corporeal "parts after the whole", these relations are not added to the essence but perfectly hold the place of such parts (perfecte gerunt vicem partium), for they determine or incline the essence of the AI to a spiritual substance disposed to receive it according to its qualitative parts. Again, Dietrich insisted, the resulting individualised AI in the soul is not a form-matter composite, for this only occurs in the case of the intellectus adeptus once the possible intellect has been elevated by grace. An analogy can, however, be made with the heart's efficient essential causality of the rest of the body or the way a form contains the entire substance of a thing in itself. ${ }^{88}$ Therefore, although the AI is an essential cause,

85 Dietrich of Freiberg, De intellectu et intelligibili, II.19.2-3, p. 159, l. 83-105.

86 Dietrich of Freiberg, De intellectu et intelligibili, II.27.4, p. 166, 1. 95-101, and II.18.1-3, p. 158, l. 70 - p. 159, l. 78 .

87 Dietrich of Freiberg, De intellectu et intelligibili, II.27.3, p. 166, 1. 90-93: Et sicut in alia manerie individuorum dictum est, quod sunt individua in habendo partes, quae sunt post totum, ita etiam suo modo se habet circa intellectum quantum ad dictos respectus, qui sunt posteriores toto, qui similiter est individuus in habendo eosdem.

Dietrich of Freiberg, De intellectu et intelligibili, II.9.1-II.11.3, p. 152, 1. 3 - p. 154, 1. 74. 
by virtue of these relations and its essential dependency on the soul's substance, it has only accidental natural being and does not belong as such to the per se order of the universe. ${ }^{89}$ Presumably, then, the individual AI belongs to the order of voluntary providence, but through its intellectual activity, the soul is related to the essential, natural order.

Berthold presupposed these arguments when he summarised the various grades of limitation comprising the second descent of the partial soul. These passages from Dietrich's treatise clarify that the partial soul's individuality must be inchoate in the unum animae and the intellectus agens in the form of QSM s. ${ }^{90}$ This would have implications for the soul's return to God, as we see in Berthold's use of Dietrich's arguments in his commentaries on Propositions 188 ("Every soul is both life and living") and 193 ("Every soul subsists proximately from an intellect"). ${ }^{91}$ We have already addressed an initial perplexity that could arise from a reading of $188 \mathrm{E}$ and ${ }_{193} \mathrm{E}$ in isolation, where it would seem that the Aristotelian (intellectus agens), Augustinian (abditum mentis or facies), Proclean (unum animae; vestigium unius), and Dionysian (unitas superexaltata mentis) candidates for the soul's highest principle were placed on equal footing. Berthold's consistent position throughout the Expositio was that the unum is "the supreme portion of the rational soul" and, more precisely, the supreme "part of intellectual substance".92 His apparent equivocation in these passages can be explained simply by pointing out that the unum animae is, ultimately, the essential cause of the soul in a primary sense, "with mind or intellect mediating". ${ }^{3}$

The reason why Berthold introduced them side-by-side in Proposition 188 was that he was concerned to explain the different kinds of "life" that heavenly and human souls may live. A principle of life can be numerically distinct from what it informs, as is the case of matter and form in a composite substance. Inspired, however, by Dietrich's De intellectu et intelligibili, Berthold proposed that other kinds of intrinsic principles of motion or life are essentially one with the substance in which they are found, and differ only intentionally or modally (intentionaliter seu modaliter). ${ }^{94}$ Such is the case for separate substances that have in themselves the principles of rational, intellectual, and divine lives.

89 Dietrich of Freiberg, De intellectu et intelligibili, II.21.2, p. 161, 1. 43-49.

90 Cf. Berthold of Moosburg, Expositio, 191E, p. 92, 1. 110-122.

91 Proclus, Elementatio theologica, prop. 188, p. 91, l. 1: Omnis anima et vita est et vivens; prop. 193, p. 94, l. 1: Omnis anima proxime ab intellectu subsistit.

92 Berthold of Moosburg, Expositio, 13D, p. 217, l. 270-284; 20H-I, p. 71, 1. 235 - p. 72, l. 275.

93 Berthold of Moosburg, Expositio, 164B, p. 31, l. 26 - p. 32, l. 34.

94 Berthold of Moosburg, Expositio, 188D, p. 63, 1. 156 - p. 65, 1. 201. 
Heavenly souls always live according to the intellectual and divine modes of life, although the way in which they exercise the latter is more hidden from us (magis nos ibidem lateat). ${ }^{95}$

As for the human soul, Berthold's consistent position was stated succinctly in the final subsections of the Expositio: because of its "partial" conjunction with the body and its passage from intellection to non-intellection, these higher forms of life are available to it only by a rapture or a kind of crossingover (raptim et secundum quendam transitum fiat aliquibus). ${ }^{96}$ The partial soul descends whole (tota) into becoming because it cannot access this perfect intellectual life spontaneously, although it always presupposes its active operation. Therefore, the soul's formal union with the operation - the state of the intellectus adeptus - that would link it to the essential order belongs to the whole soul (totius animae) only accidentally. ${ }^{97}$ Nevertheless, Berthold's interpretation of the anthropological exemplarism of the Clavis through Dietrich of Freiberg led him to add one important qualification to Proclus, which was signalled in his application of Proposition 65 to the case of the partial soul in 211A: because of its inwardness (intraneitas) that is not joined with the body, the partial soul does not descend totally (totaliter) into becoming. ${ }^{98}$ According to Berthold, even though the human soul's alienation from its own ground cannot be fully overcome in this life, it can be mitigated through the process of recollection. Since true philosophy embraces logic, natural philosophy, and ethics, ${ }^{99}$ the spiritual exercise of the soul's oblique motion through the study of the Elementatio theologica, with its logical rigour and attention to natures outside the soul, must coincide with ethical practice. As the soul gradually separates itself from bodily affections, it recollects (recordetur) the knowledge that

95 Berthold of Moosburg, Expositio, 188E, p. 65, l. 23o; 193E, p. 103, l. 126 - p. 104, l. 134.

96 Berthold of Moosburg, Expositio, 211F, p. 263, l. 216.

97 Berthold of Moosburg, Expositio, 211F, p. 264, 1. 246-248: Quamvis enim aliquid eius semper stet in lumine actualis intelligentiae intelligendo se ipsum et suum principium, a quo intellectualiter et cognitive emanat, tamen ista cognitio non est totius animae nisi per accidens.

98 Berthold of Moosburg, Expositio, 211E, p. 263, 1. 192-8: Et sic omnis anima partialis per essentiam et se tota manet in suis primordialibus causis et tota procedit seu descendit non solum in suam propriam existentiam, sed etiam in generationem. Sed non totaliter, quia non secundum omnem modum, quo est in suis primordialibus causis quoad primum descensum, nec secundum omnem modem, quo est in ente, quamvis nihil pertinens ad ipsius talis animae substantiam, prout descendit in generationem, maneat in ente quoad secundum descensum sive in esse intellectuali.

99 Berthold of Moosburg, Expositio, Prol. 20, p. 32, l. 884 - p. 34, l. 973; Expos. tit. L, p. 5o, 1. 441-47o. 
belongs to that principle of intellectual life. ${ }^{100}$ Insofar as it quiets even these interior movements, the soul lives the divine life. ${ }^{101}$ The theory of recollection provided the means of mediating the soul's alienation from the ongoing activity in its ground and the gradual approximation of it through the discipline of the oblique motion.

The place of the theory of recollection in Berthold's account of the soul's double descent is most clearly defined in Proposition 207. Here Berthold used the doctrine of recollection to interpret Proclus' statement that the first body of the partial soul is incorruptible because "it is established from an immobile cause". The soul's mode of knowing requires an appropriate kind of body. Since the soul's modes of knowing in being and in becoming are so unlike, so too are the kinds of body the soul uses: it requires a spiritual body when it is in being (in ente) and is conformed to the presiding gods (conformis diis praesidibus) or contemplating them (contemplatrix deorum), as "divine" and "intellectual" souls always are; but when it is in becoming (in generatione) and has fallen into "forgetfulness", it uses a material body. ${ }^{102}$ For the Platonists, if the soul had remained in its natural order (in ordine naturali), it would know things outside itself through the intelligible species with which the creator endowed it and would not have to beg for intelligibility (mendicare species intelligibiles ab

100 Berthold of Moosburg, Expositio, 211E, p. 264, 1. 222-228: Sed pro tunc solvitur secundum Platonicos unio superioris partis, quod supra dixi principium intellectualis, a residua portione substantiae ipsius animae, ne sit forma eius, licet ista solutio fiat plus et minus. Et per consequens ipsa anima in unione sui ad corpus materiale secundum proportionem talis solutionis obliviscitur eorum, quae prius existens in ente scivit, licet recordetur postea sedatis humoribus doctrina ventilante ad publicum semen veri, quod intus erat, sed in abdito latitabat. Cf. Dietrich of Freiberg, De cognitione entium separatorum, 94.6, p. 258, 1. 3542: Ut enim attrahamus ad huius rei restitutionem sententiam Platonicorum, videbimus eos concordare nobiscum in hac re. Dicunt enim, quod anima rationalis separata portat secum omnes artes, sed ex coniunctione sui ad corpus cadit in oblivionem earum. Sed istam sententiam Platonicorum quantum ad hoc, quod videtur sonare, quod anima fuerit informata omnibus artibus ante infusionem suam in corpus, et per consequens, quod dicit de causa oblivionis, non recipimus, cum teneamus et fateamur animam in sui infusione creariet in sua creatione infundi. Berthold's phrase ad publicum semen veri echoes Boethius, Consolatio philosophiae, lib. III, metrum 11. Cf. Berthold of Moosburg, Expositio, 194F, p. 114, l. 209-231; 207A, p. 225, l. 13 - p. 226, 1. 58; 207D, p. 228, l. 111-124.

101 Berthold of Moosburg, Expositio, 202C, p. 186, l. 167-171. Cf. Proclus, De providentia et fato, c. 8, §31, p. 140, l. 11-12: quo adiaciens le unum quietem amat, clausa cognitionibus, muta facta et silens intrinseco silentio.

102 Berthold of Moosburg, Expositio, 207A, p. 225, 1. 18-21: Secundum Platonicos vero anima partialis - secundum duplicem sui statum, quem alternare potest in infinitum, per praemissam - alio indiget susceptaculo, prout est in ente conformis diis praesidibus (quando videlicet est contemplatrix deorum), alio vero, quando est in generatione cadens in oblivionem. 
extra). ${ }^{103}$ One might say that it would always know itself, according to the circular motion, and the world, according to the direct motion. To exercise these motions perfectly, as the higher souls always do, the partial soul would need a body like theirs, which Berthold described using the attributes Paul applied the resurrected body (impassibility, clarity, subtlety, and agility). ${ }^{104}$ Looking at the soul's present embodied condition, however, Aristotle was right to say that it must begin knowing by abstracting species from material things. In this sense, the material body is appropriate to initiate the process of recollection. Plato "did not deny this path", but held that such a view must always be balanced by the doctrine of recollection, which Berthold found authoritatively expressed by Boethius: "Now, the body bringing forgetful weight / does not expel all light from the mind; / within, there assuredly abides the seed of truth, / which is aroused by instruction fanning the ember". ${ }^{105}$ For the Platonists, the soul's proper and vivid cognition has been obscured by the passions (confunditur passionibus). This is why Berthold can argue at the end of Proposition 211 that, even though a part of the soul always stands in the light of actual intelligence - always recollecting its content through the universality that belongs to the human species - the whole soul is far removed from that light.

As Berthold put it before the concluding prayer of the Prologus, the wayfarer is so remote from the font of paternal light because it is so distracted by cares, occluded by imaginings, and bound up in lust. ${ }^{106}$ This light, whose "splendour is the Word", illuminates all people "coming into this world" (cf. John 1:9). It is very important to note that Berthold, playing on the phrase in hunc mundum ("into this world" or "into this pure [state]"), then reverses the more familiar interpretation of the verse. That is, the true light does not illumine all people equally who are born into the world of becoming - or, at least, it is not received equally by all. Rather, as Berthold made clear, it illumines only those who "come into intellectual purity" (illuminat omnem hominem venientem in

\footnotetext{
103 Berthold of Moosburg, Expositio, 207C, p. 227, l. 94-10o.

104 Berthold of Moosburg, Expositio, 207A, p. 226, l. 40-58. Cf. 1 Corinthians 15:39-54.

105 Berthold of Moosburg, Expositio, 207C, p. 227, l. 100 - p. 228, l. 110; 207A, p. 225, l. 31 p. 226, l. 34. Cf. Boethius, Consolatio philosophiae, lib. III, metrum 11, p. 91, l. 9-12.

106 Berthold of Moosburg, Expositio, Prol. 21, p. 34, l. 968-973: Ex praemissis patere potest, cum quanta difficultate anima etiam deiformis effecta in hac vita ascendat ad conspectum fontis paternae lucis, cuius splendor gloriae est Verbum, 'lux vera, quae illuminat omnem hominem venientem in hunc mundum, scilicet puritatem intellectualem, a qua longe est mens hominis sollicitudinibus distracta, phantasmatibus obnubilata, taceo autem de carnalibus voluptatibus implicata. The final phrases (sollicitudinibus distracta, etc.) come from Bonaventure, Itinerarium mentis in Deum, in PP Collegii S. Bonaventurae (eds), Opera omnia, vol. 5 (Quaracchi: Collegium S. Bonaventurae, 1896), c. 4, §1, p. 306a.
} 
hunc mundum, scilicet puritatem intellectualem). ${ }^{107}$ Again we are confronted with the paradox that the cognition that belongs to the soul by nature as an ens secundum speciem is by nature inaccessible to it as an individual ens hoc. The exemplarist turn Berthold gave to the doctrine of recollection meant that the fullness sought by recollection somehow must belong to human nature as it subsists in the mind of God - in effect a combination of the Eriugenian anthropology of the duplex speculatio with the Proclean notion of imitating the divine providence. Just as the ceaseless cognition of the ground of the soul remains hidden to us, so does the spiritual body abide still "in the hidden folds of nature". ${ }^{108}$ According to the doctrine of the double descent, as Berthold interpreted it through Dietrich of Freiberg's De intellectu et intelligibili, individual souls created de novo are related to this plenitude through the unum animae and intellectus agens, which are simultaneously individuated and universalising powers. We can turn now to consider the content of what for Berthold was the highest approximation of that state a soul could reach in this life: the transitory enjoyment of the state he understood to be the goal of the study of the Elementatio theologica, namely, puritas intellectualis.

\section{The Goodness of Silence: Deification and Providential Cognition}

Berthold's Eriugenian interpretation of the Proclean spiritual body (susceptaculum) coincided with the single most direct criticism of Proclus in the Expositio. Berthold insisted three times, each time using the Clavis physicae, that souls who fully enjoy blessedness after death can never fall. This criticism was made at the conclusion of Proposition 196, again in 206, and finally in 209, as Berthold cited the Clavis on the beatitude "promised to the saints" and the macrocosmic reversion of all temporal things into their primordial causes, when "God alone shall appear in them". ${ }^{109}$ This return of creatures to their

107 Cf. Meister Eckhart, Sermo VI/2 (First Sunday after Trinity), eds E. Benz, B. Decker, J. Koch, Die lateinischen Werke, vol. 4 (Stuttgart: Kohlhammer, 1956), §57-58, p. 57, l. 3 - p. 58, l. 3: Ubi nota primo, quod deus verissime mittit, gignit unigenitum suum in anima munda et 'in ipso et per ipsum omnia', se ipsum, Ioh. 14: 'ad eum veniemus' etc. [...] <Tertio > dic: in mundum. Non dicit: 'in hunc mundum' [1 John 4:9], sed in mundum simpliciter. Igitur in mundum intellectualem, secundum Platonem. See also Albert the Great, De intellectu et intelligibili, lib. II, tr. unicus, c. 10, p. 518a-b, cited at 1.2, n. 79, above, and the citation of Dionysius at Expositio, Prol. 17, p. 26, 1. 685-689.

108 Berthold of Moosburg, Expositio, 196F, p. 128, l. 19o-2; 195D, p. 119, l. 99-118.

109 Berthold of Moosburg, Expositio, 196F, p. 170, l. 64-5: Non autem video quomodo homo beatitudinem perderet si eam re ipsa plene perfecteque gustaret; 206F, p. 223, 1. 261-266: Istius autem descensus animarum vult auctor in infinitum vicissitudines permutari, quod non 
causes transpires only when creatures doff the finitude of time and place and revert to their infinite eternal principles while their nature remains intact; for the microcosm, the full enjoyment of that vision, understood in this sense of being "filled" with the plenitude of divinity by grace just as the humanity of the Son was filled with divinity by nature, precludes the possibility of any temporal pre-existence in such a state or a subsequent lapse from the beatific vision.

The central refutation of Proclus on re-embodiment is found in Proposition 206 ("Every partial soul can descend into generation and ascend from generation into being an infinite number of times"). ${ }^{110}$ Rather than rejecting the view outright by merely contrasting it with the authoritative doctrine of the faith, Berthold was more interested in giving it an acceptable metaphorical meaning. We should remember that, for Berthold, Proclus belonged alongside Plotinus as a philosopher who lifted the coverings (integumenta) with which the earliest Platonists had enshrouded Plato's theorems (theoremata). Although he did not recall this history of Platonism at this stage of the Expositio, it seems likely that Berthold regarded the literal interpretation of reincarnation he found in Macrobius and Proclus as either a further act of concealment or, more plausibly, a failure to pierce all the way through those mythical coverings. His language of refutation in ${ }_{209} \mathrm{~F}$ (refellitur) would suggest the latter view. In either case, the search for an acceptable metaphorical meaning of reincarnation was required if Berthold was to demonstrate the thorough compatibility of the best of the pagan philosophers with the greatest theologian Paul (summus divinalis sapientiae theologus Paulus), his disciple Dionysius, and his commentators. To this end, he was assisted by Albert the Great's De natura et origine animae, where the mythical soteriology of the Platonists is presented chiefly as an account of the soul's origin, its immortality, and its natural yearning for knowledge. ${ }^{111}$

videtur intelligibile; anima enim fruens fonte omnium bonorum utpote beata et felicis vitae nec timore torqueri potuerit nec falsa securitate decipi nec commutabili bono allici ut, volens, a bono incommutabili se avertat nec ad aversionem ab aliquo violentari; $209 \mathrm{~F}, \mathrm{p} .245$, l. 201: per hoc iterum refellitur descensus animarum.

110 Proclus, Elementatio theologica, prop. 206, p. 101, 1. 1-2: Omnis anima partialis descendere in generationem in infinitum et ascendere potest a generatione in ens.

111 Albert the Great, De natura et origine animae, ed. B. Geyer (Münster i.W.: Aschendorff, 1955), tr. 2, c. 7, p. 30, 1. 30 - p. 31, l. 67. See also Albert the Great, Summa theologiae, ed. A. Borgnet, vol. 33 (Paris: Vivès, 1895), pars II, tr. 12, q. 72, m. 4, a. 3, p. 51a-b: Ad dicta Marcobii dicendum, quod fabulosa sunt, et integumenta eorum quae dixerunt Gentiles idolotrae [...]. Ad aliud dicendum, quod non intellexit Macrobius, nec etiam Plato, quod anima rationalis vires acciperet in stellis: quia potentiae animae a substantia et esse animae fluunt. 
Berthold began Proposition 206 by noting that the word "place" (locus) in the strict sense applies only to the corporeal realm of becoming. It also has a "metaphorical" meaning for spiritual realities, where the higher is "located" by the lower as what is "more exterior", and the lower is "located" by the higher as what is "more interior". 112 Here we may think of the hierarchy of cognition outlined in $123 \mathrm{D}$, where the ascent to higher modes of knowing coincides with the apprehension of more fundamental aspects of the object. With this caveat about metaphor, Berthold was preparing for the argument that the notion of companion stars (stellae compares) in the Timaeus $42 \mathrm{~b}$, the "place" whence souls arise and whither they return, must be understood in the metaphorical sense. ${ }^{113}$ Platonists speak this way, he explained, because of their account of the origin of the partial soul, which holds that the constellations exercise a determinative operation through the influence of intellectual light, through which a celestial mover scatters intellectual seeds proportionate to itself within the soul. ${ }^{114}$ Berthold went so far as to claim that this accords with those (e.g., Augustine) who say that souls "are poured in by being created and are created by being poured in" (creando infundi et infundendo creari). ${ }^{115}$ With this simple manoeuvre, Berthold stripped Platonic doctrine of its association with the doctrine of the pre-existence of souls, such that it becomes an account of the soul's intellectual origins and its natural desire to return to the interiority where it can live the life most appropriate to it. ${ }^{116}$

112 Berthold of Moosburg, Expositio, 206A, p. 216, l. 14 - p. 217, l. 37. Cf. Dietrich of Freiberg, De substantiis spiritualibus et corporibus futurae resurrectionis, 14.2-3 and 14.4-6, p. 313, l. 16-21 and 30-38.

113 Berthold of Moosburg, Expositio, 206B, p. 217, l. 39 - p. 218, 1. 75 .

114 Here Berthold also looked to Macrobius (In Somnium Scipionis I.14), whom he cited on the "fiery" intellect which the souls receive from the higher stars of the Milky Way $(207 \mathrm{E})$, along with Boethius' poetic images of recollection as glowing embers kindled by teaching (207A-C). This account of the human soul's origin would be compatible with what he found in Albert the Great, De natura et origine animae, tr. I, c. 5, p. 14, 1. 14-27.

115 Berthold of Moosburg, Expositio, 206B, p. 217, 1. 51-54: Et in talem sententiam concordant etiam isti, qui dicunt animas creando infundi et infundendo creari ita, quod usque hodie in circulis nativitatem ponitur ab eis una stella, quam Hyleg et Alkocoden vocant, quod Latine sonat vita et intellectus, eo, quod nato vitam et intellectum conferre dicitur. See also Expositio, 207C, p. 227, 1. 78-82.

116 Berthold of Moosburg, Expositio, 206B, p. 218, 1. 62-69: Videtur autem haec positio accipi ex quattuor motivis praecipuis: tum quia animarum partialium cum intellectualibus et divinis est eadem natura, cum sint eiusdem seyrae, ergo et idem locus; tum quia anima partialis non debetur corpori terrestri nisi propter similitudinem eius ad caelum, igitur caelum est magis proprius eius locus; tum quia anima partialis est quasi semen motorum caelestium secundum expositionem Calcidii super Timaeo: ergo eorum erit ad eundem locum comparitas; tum etiam quia sunt eiusdem operationis, scilicet intellectualis. 
More important still was Berthold's account of the soul's proper work in its native "place" at 206C (quid autem animae partialis in comparibus stellis existentis opus sit), where he forged a synthesis of Proclus and Dionysius on the question of beatitude and embodiment. ${ }^{117}$ This comparative approach has been followed unwittingly in more recent times by Jean Trouillard, who has contrasted Eriugena, whom he judged to follow Dionysius, and Proclus on precisely this question. Drawing on the Tria opuscula and Proclus' commentary on the Republic (unknown to Berthold), Trouillard saw differences between the two Platonists where Berthold found similarities. ${ }^{118}$ Trouillard was emphatic that, for Proclus, separated souls rejoice at the prospect of being reunited with a body. Virtuous and vicious souls alike find in their return to body the opportunity for action, although they descend for different reasons - some out of generosity and self-sacrifice, and others out of forgetfulness. Berthold was in fact aware of this view and cited the key passage from the De malorum subsistentia: souls descend either because of "the inability to imitate the presiding [gods], the desire for noble birth, purity, virtue, [or] divine intellect".119 Berthold's first citation of De malorum subsistentia in 206C, regarding the soul's work in heaven, is also one that Trouillard would regard as characteristically Proclean:

For the primary good is not contemplation, intellective life, and knowledge, as someone has said somewhere. No, it is life in accordance with the divine intellect which consists, on the one hand, in comprehending the intelligibles through its own intellect, and, on the other, in encompassing the sensibles with the powers of [the circle of] difference and in giving even to these sensibles a portion of the goods from above. For that which is perfectly good possesses plenitude, not by the mere preservation of itself, but because it also desires, by its gift to others and through the ungrudging abundance of its activity, to benefit all things and make them similar to itself. ${ }^{120}$

117 Berthold of Moosburg, Expositio, 206C, p. 218, l. 77 - p. 219, l. 110.

118 J. Trouillard, "Métensomatose proclienne et eschatologie érigénienne", in J. Sojcher, G. Hottois (eds), Philosophies non-chrétiennes et christianisme. Annales de l'Institut de Philosophie et de Sciences morales (Bruxelles: Université libre de Bruxelles, 1984), p. 87-99.

119 Berthold of Moosburg, Expositio, 206D, p. 220, l. 140-2.

120 Berthold of Moosburg, Expositio, 206C, p. 218, l. 83-89, citing Proclus, De malorum subsistentia, c. 7, §23, p. 202, 1. 10-18: Non enim erat prime bonum thea, id est speculatio, vel intellectualis vita et prudentia, ut alicubi ait aliquis, sed quod secundum divinum intellectum detinens quidem intellectualia sui ipsius intellectu. Ambiens autem sensibilia his quae alterius potentiis et eorum quae inde bonorum partem etiam ipsius his exhibens, quia, quod perfecte bonum non in salvare se ipsum solum habet le plenum, sed iam et ea, quae ad 
Rather than addressing the theme of the soul's desire for embodiment, however, Berthold focused on the term plenum, and connected this passage with one immediately preceding it, where Proclus stated that blessed souls in the realm of being "feast" with the gods: "with the presiding gods the soul ascends $[\ldots]$ to the fruition of divine things and especially of the primarily Good". ${ }^{121}$ According to Berthold, on this point Proclus in fact agreed with Dionysius, who wrote:

This, therefore, according to my knowledge, is the first rank of heavenly beings standing immediately in the circuit of God [in circuitu] and around God, simply and unceasingly encircling his eternal cognition in the highest arrangement beyond motion. This is what we find in the angels, who view many blessed contemplations purely, and who are illumined by simple and immediate splendours, and filled with divine nourishment [divino nutrimento adimpletus] - many, indeed, [are filled] by the first effusion that is bestowed, but one [rank] by the invariable and life-giving unity of the thearchic banquet [invariabili et vivifica thearchicae epulationis unitate]. ${ }^{122}$

According to Berthold, who did not mention that this passage referred to the seraphim at the summit of the angelic hierarchy, both texts describe the stable contemplation enjoyed by "divine souls" (the movers of the heavens) and "intellectual souls" (human souls in being). The language of feasting and plenitude, he argued, suggests that we are dealing with an activity that is connatural to the soul, and if it is given fully without impediment, then it does not have a contrary (si est non impedita, non habet contrarium). This simple point

alia datione et non invidiosae operationis omnia bonifacere desiderat et sibi similia facere. English translation: Proclus, On the Existence of Evils, trans. J. Opsomer, C. Steel (Ithaca, NY: Cornell University Press, 2003), p. 73-4.

121 Berthold of Moosburg, Expositio, 206C, p. 218, l. 91-93: Ex quibus verbis aperte colligitur animam partialem, ut est in ente, esse beatam, sicut quae cum diis praesidibus ascendit ad felicem et perfectissimam entis epulationem, id est ad fruitionem divinorum et specialiter prime boni.

122 Berthold of Moosburg, Expositio, 206C, p. 218, 1. 95 - p. 219, l. 101, citing Dionysius, De caelesti hiearchia, 7.4, 212A: Igitur hic quidem est secundum meam scientiam primus caelestium substantiarum ornatus in circuitu Dei et circa Deum sine medio stans et simpliciter et indesinenter ambiens aeternam ipsius cognitionem secundum supremam, ut in angelis, supermobilem collocationem; multis quidem et beatis videns pure contemplationibus, simplicibus autem et immediatis splendoribus illuminatus: et divino nutrimento adimpletus, multa quidem, primo data effusione, una autem, invariabili et vivifica thearchicae epulationis unitate. 
was meant to establish that Proclus was mistaken to assert that souls would ever descend from their homes among their "companion stars", but the Clavis had it right: if ever souls delight in the immutable fount of all goods, nothing could draw them away. ${ }^{123}$ Thus Berthold read Proclus through Eriugena (and Dionysius) for whom, as Trouillard observed, the perfection of the soul is precisely to be "saturated by contemplation".

The soul naturally longs for the kind of incorruptible body that "whole" heavenly souls have already, and which will serve it in the greater realisation of contemplative felicity. ${ }^{124}$ What a spiritual body enables, with the qualities of agility, subtlety, and so on, is the further transmission of the goods that the souls receive from intellects above them. For Berthold, souls do in a sense ascend and descend from being into becoming in rare moments of contemplative raptus, but to say that a soul would descend from the permanent possession of its own intellect (intellectus adeptus), is unthinkable. The Dionysian correction of Proclus, which for Berthold truly grasped the doctrine behind the Timaeus, which Proclus should have understood by the light of his own principles, was that the soul does not turn directly back to the world of generation and corruption, but exercises a divine care for what is below because of a kind of excess or overflow. As Proclus himself wrote, the soul raised to "govern the world with the gods" by "ascending to the blissful and most perfect banquet of being", fills those who follow upon it with that same abundance. ${ }^{125}$ This idea immediately preceded Proclus' remark, cited above, that "the primary good is not contemplation" or "intellective life". So too for Dionysius, hierarchy is intended to connect the higher and lower through such a dynamic exchange. ${ }^{126}$ If contemplation does not result in some providential action, if it does not abound, then it is not yet divine.

123 Berthold of Moosburg, Expositio, 206F, p. 223, l. 263-6: anima enim fruens fonte omnium bonorum utpote beata et felicis vitae nec timore torqueri potuerit nec falsa securitate decipi nec commutabili bono allici ut, volens, a bono incommutabili se avertat nec ad aversionem ab aliquo violentari.

124 Berthold of Moosburg, Expositio, 185H, p. 24, l. 334 - p. 25, l. 365; 202C, p. 185, l.127136: quando incorruptibiles et immortales erimus et christiformem et beatissimum consequemur finem, visibili ipsius Dei apparitione in castissimis contemplationibus adimpleti, manifestissimis circa nos splendoribus refulgente, sicut circa discipulos in illa divinissima transformatione; intelligibili autem luminis datione ipsius, impassibili et immateriali mente participantes et super mentem unitione, in ignotis et beatis immissionibus superclarorum radiorum, in diviniore imitatione supercaelestium mentium. Nam aequales erimus angelis, ut veritas dicit Eloquiorum, et filii Dei, resurrectionis filii existentes.

125 Berthold of Moosburg, Expositio, 206C, p. 218, 1. 8o-83, cited above at 5.1, n. 63.

126 Dionysius, De caelesti hierarchia, 3.2, 165A-C. 
In this respect, we see that Berthold attempted to be faithful to Proclus' own doctrine set out in Proposition 129 ("Every divine body is divine through a deified soul; but every soul is divine because of a divine intellect; but every intellect is divine through participation in a divine unity: and if the One is antotheon, that is, God from itself, intellect is most divine, soul is divine, and body is deiform"). ${ }^{127}$ Proclus' terminology prompted Berthold to discuss the meaning of deification (deificatio). If the body is to be deified, this must occur "through assimilation and union" with God, as Dionysius wrote. This can only happen through the intermediary terms, such that "the body would be, as it were, changed into soul, soul into intellect, and intellect into God".128

Here, once again, Berthold's guide to interpreting Proclus on deification was the Clavis physicae. ${ }^{129}$ Berthold first included the famous images of light-filled air and red-hot iron, which Eriugena elaborated from Maximus the Confessor, and which subsequently were included in the Clavis. ${ }^{130}$ These metaphors originally were intended to illustrate how the divine and the human can be united without confusion or, in the more universal scope of Eriugena and Berthold, how a lower nature can be infused and transformed by the higher without losing its identity: the corporeal is changed into the soul, "not so that it would be lost", but "to preserve it in a better essence".

To get a clearer sense of how this will occur in the macrocosm, Berthold continued, let us take as an example the deified person (ponamus hominem deificatum pro exemplo), in whom the four cosmological genera are present. He then cited the two familiar texts from Dionysius and Proclus - Dionysius on "the unity exceeding the nature of mind", according to which it is necessary to think divine things, "not according to ourselves", and so on; and Proclus, who made this point more clearly (istam intentionem clarius ponit Proclus), when he disclosed the frenzy or cognition above mind, in which the soul "sees" the One by "not seeing", having brought all exterior and interior motions to stillness.

127 Proclus, Elementatio theologica, prop. 129, p. 65, l. 1-5: Omne corpus divinum per animam est divinum exdeatam, omnis autem anima divina propter divinum intellectum, omnis autem intellectus divinus secundum participationem divine unitatis; et si quidem unum autotheon [Berthold: antotheon] (id est ex se) deus, intellectus autem divinissimum, anima autem divina, corpus autem deiforme. On this commentary, see E. Massa, "La deificazione nel commento di Bertoldo di Moosburg a Proclo, Elementatio theologica, 129. Edizione del testo e prime analisi", in R. Lievens, E. van Mingroot, W. Verbeke (eds), Pascua Mediaevalia. Studies voor Prof. Dr. J.M. de Smet (Leuven: Leuven University Press, 1983), p. 545-604.

128 Berthold of Moosburg, Expositio, 129B, p. 177, l. 140-141: quod corpus quasi mutetur in animam, anima in intellectum, intellectus in Deum.

129 Berthold of Moosburg, Expositio, 129B, p. 177, l. 142 - p. 179, l. 196.

130 See Gersh, From Iamblichus to Eriugena, p. 193-203. 
According to Berthold, this shows that, although the preparation or purification of the soul begins from below, deification begins from above, when God is participated separably (separabiliter) through the unum animae, which is the inseparable potency (per inseparabilem potentiam) or vestige God has left in the soul. Then the intellect is transformed and made most divine (divinissimum), and so on for the soul and for the body. In this way the participation in divinity passes through all intermediaries to the deification of the body (sic participatio divinitatis transit per omnia media usque ad deificationem corporis).

Among these more familiar sources, it is most striking to find Berthold citing Bernard of Clairvaux, as a confirmation of the consensus of the Clavis and Proclus about the deification of the microcosm (intended, we will recall, as an illustration of what will transpire in the macrocosm):

And so, as Bernard says, 'the whole person will proceed into God and, adhering to him, from thenceforth will be one spirit with him'. 'Just as a tiny drop of water infused in a large quantity of wine seems to leave itself, and now is imbued with the taste and colour of wine', 'so also, at that time, in the saints' (that is, 'when they are drunk, so to speak, with the abundance of the house of God, and in some way will have become oblivious of themselves'), 'all human affection will necessarily, in some ineffable way, liquify and be poured out deeply into the will of God. Otherwise, how will God be all in all, if in man something of man will remain? Indeed, the substance will remain, but in another form, another glory, and another power. ${ }^{131}$

This citation brought together and reordered numerous phrases from Bernard's De diligendo Deo. This reordering, and the reference to Ephesians 3:19 that immediately follows it in the Expositio, indicate that Berthold's source was a popular florilegium, the so-called Flores Bernardi. ${ }^{132}$ This chapter of the

131 Berthold of Moosburg, Expositio, 129B, p. 179, l. 188-196: Et sic, ut dicit Bernardus, 'totus homo perget in Deum et deinceps adhaerens ei unus cum eo spiritus erit'. 'Quomodo stilla aquae modica multo infusa vino deficere a se tota videtur, dum et saporem vini induit et colorem,' 'sic omnem tunc in sanctis' (scilicet 'quando quasi ebrii ab ubertate domus Domini quodammodo obliti sui ipsorum fuerint') 'humanam affectionem quodam ineffabili modo necesse erit a semet ipsa liquescere atque in Dei penitus transfundi voluntatem. Alioquin, quomodo erit Deus omnia in omnibus, si in homine de homine quidquam supererit? Manebit quidem substantia, sed in alia forma, alia gloria, aliaque potentia.

132 Bernard of Clairvaux, De diligendo Deo, eds J. Leclercq, H. Rochais, Sancti Bernardi Opera, vol. 3 (Roma: Editiones Cistercienses, 1963): totus ... erit (c. 15, §39, p. 153, l. 9-10); quomodo ... colorem (c. 10, §28, p. 143, l. 15-17); sic ... sanctis (c. 10, §28 p. 143, l. 20); quando ... fueriunt (cf. c. 15, §39, p. 153, l. 7-8); humanam ... potentia (c. 10, §28, p. 143, 1. 20-24). 
Flores embellished Bernard's own summary of the argument in De diligendo Deo about of the four ascending modes of love, according to which a person (1) loves oneself for one's own sake, (2) loves God for one's own sake, (3) loves God for God's sake, and (4) loves oneself for God's sake. ${ }^{133}$ In the lengthier discussion of the fourth mode in chapter 10 of De diligendo Deo, Bernard spoke of the rare possibility of attaining such love in this life, if only for an instant. ${ }^{134}$ In the summary at chapter 15 , however, which was retained by the Flores, the glass was half empty, and Bernard hesitated to affirm that the fourth mode could be attained "perfectly" in this life. ${ }^{135}$ This would not have had a significant bearing on Berthold's analysis of Proposition 129, where the perspective was clearly that of the Resurrection and the total deification of the microcosm, but it will be worth keeping in mind when we return to consider Berthold's conception of the transitory cognition of the unum animae.

In one sense, Bernard only confirmed what Berthold already took from the Clavis, with the metaphors of mixture illustrating how the substance of

I have not been able to consult a manuscript of the florilegium written before the $15^{\text {th }}$ century. Of the modern editions, the text used by Berthold was closer to Flores sancti Bernardi (Venezia: Junta, 1503), lib. IX, c. 42, p. 162vb, than what is found in Flores operum D. Bernardi abbatis Clarevallensis (Lyons: G. Rouillius, 1570), lib. IX, c. 36 , p. 698, as the latter makes no reference to the domus Domini. In both editions, the next and final chapter of book IX is De longitudine, latitudine, sublimitate et profundo - a clear echo of Eph. 3:19, discussed below - which summarised Bernard of Clairvaux, De consideratione, lib. v, c. 13, §27. On the origins and medieval transmission of the Flores Bernardi, see M. Bernards, "Flores Sancti Bernardi", in J. Lortz (ed.), Bernhard von Clairvaux. Mönch und Mystiker. Internationaler Bernhard-Kongress Mainz 1953 (Mainz: Veröffentlichungen des Instituts für europäische Geschichte Mainz, 1955), p. 176-191, and U. Köpf, "Die Rezeptions- und Wirkungsgeschichte Bernhards von Clairvaux. Forschungsstand und Forschungsaufgaben", in K. Elm (ed.), Bernhard von Clairvaux. Rezeption und Wirkung im Mittelalter und in der Neuzeit (Wiesbaden: Harrassowitz, 1994), p. 5-65, at p. 12-17. The same passage from the Flores used by Berthold featured prominently in Henry Suso's account of releasement (gelazsenheit) in The Little Book of Truth. See Henry Suso, Daz buechli der warheit, c. 4, p. 336, l. 7-24. On Bernard's influence among Berthold's Dominican contemporaries, see G. Steer, "Bernhard von Clairvaux als theologische Autorität für Meister Eckhart, Johannes Tauler und Heinrich Seuse", in K. Elm (ed.), Bernhard von Clairvaux, p. 233-259.

133 Bernard of Clairvaux, De diligendo Deo, c. 15, §39, p. 152, l. 18 - p. 153, l. 14.

134 Bernard of Clairvaux, De diligendo Deo, c. 10, \$27, p. 142, 1. 13-15: Beatum dixerim et sanctum, cui tale aliquid in hac mortali vita raro interdum, aut vel semel, et hoc ipsum raptim atque unius vix momenti spatio, experiri donatum est.

135 Bernard of Clairvaux, De diligendo Deo, c. 15, §39, p. 153, l. 3-6: Sane in hoc gradu diu statur, et nescio si a quoquam hominum quartus in hac vita perfecte apprehenditur, ut se scilicet homo diligat tantum propter Deum. Asserant hoc si qui experti sunt; mihi, fateor, impossibile videtur. 
beatified human nature remains while it is imbued by grace with another glory and another power, so that God may be "all in all". ${ }^{136}$ Just as water takes on the properties of wine, or iron the properties of fire, so human nature is ennobled by the divine nature. But the imagery used by Bernard (the banquet in the house of God, drunkenness, and self-forgetfulness) went further than this, and struck a deeper resonance with more characteristic motifs of the doctrine of contemplation in the Expositio, which have more in common with Proclus and Dionysius than with the Clavis. The banquet, with the semantic register of abundance and plenitude, was central to Berthold's understanding of how deification occurs as an overflow from the top, so to speak, of the macrocosm and microcosm. Such metaphors appeared at the culmination of his gloss on Psalm 42 at the conclusion of the Prologus, with the famished soul's arrival to the house of God (the vision of the divine ideas) and the heavenly banquet (usque ad domum Dei, in voce exultationis et confessionis sonus epulantis). Similarly, the correction of Proclus' literalist reading of Plato's myths of embodiment with the Dionysian theology of the Clavis hinged on the idea that the soul's proper activity in the realm of being is a feast (epulatio), whose overabundance redounds providentially to its body and all who follow after the soul. ${ }^{137}$ Bernard's association of the banquet - with "the house of the Lord" surely signifying for Berthold the primordial causes in the Word - with the drunkenness of the saints (quasi ebrii) and their self-forgetfulness (obliti sui ipsorum) would have aligned with Berthold's own understanding of the unum animae as a nonreflexive ignorance of self that exceeds and grounds the self-reflexivity of the acquired intellect $(123 \mathrm{D})$. These themes are found in the immediate context of 129B with Dionysius (totos nos ipsos extra totos nos ipsos statutos / melius est enim esse Dei et non nostri ipsorum) and with Proclus' metaphor of the divine frenzy of stillness (divina mania / quietens se ipsum).

The citation of Bernard also sheds new light on Berthold's understanding of the unum animae. In a work as vast and methodical as the Expositio, which so

${ }_{136}$ The same description of unitive cognition by "the flower of the intellect" used at $129 B$ was cited at ${ }_{114} \mathrm{~B}$, when Berthold maintained that Proclus was describing deification by grace (per gratiam). See also Berthold of Moosburg, Expositio, 120C, p. 93, l. 97-107.

137 Berthold of Moosburg, Expositio, 206C, p. 218, 1. 82-83: et quae in ipsam respicientia replens eo, quod ibi nectare; 209A, p. 240, 1. 21-31: Est et alius ordo, scilicet supernaturalis [...] et pertinet ad statum vitae felicis, quo anima cum suo susceptaculo, quod primitus animat, est in ente, ad quem statum pertinet non solum gloria animae in fruendo per contemplationem et dilectionem fonte boni, ex cuius superplenitudine ipsa anima partialis utpote supercaelestis existens illuminatur, immo superimpletur divini luminis claritate, verum etiam gloria ipsius susceptaculi; 209E, p. 244, l. 158-171: ubi degustat et copiosam alimentorum divinorum affluentiam et inebriatur divini nectaris ubertate. 
rarely departs from the parameters set by Proclus' philosophical vocabulary, the value of a passing reference or citation for understanding Berthold's unspoken assumptions can be inversely proportional to its quantitative presence. This has been the case with the intellectus adeptus in $123 \mathrm{D}$, which was crucial for grasping Berthold's modifications of Dietrich's views about the roles of grace and reflexivity in the vision of God, and with the Prologus' astrologer who "governs the world with the gods", which enabled us to see how Berthold adapted Albert's notions of the acquired and assimilative intellects and prophecy to a Platonic register. If there is one thing that these phrases from Bernard introduce that was altogether absent from the recurring citations of Proclus and Dionysius on the unum animae, it was not the notion that the transformation of human nature occurs by grace, in which there is no confusion of humanity and divinity, but the idea that this occurs through a union of wills (unus cum eo spiritus erit / humanam affectionem in Dei penitus transfundivoluntatem).

The echo of Ephesians 3:19 that immediately followed the citation of Bernard in 129 B ("thus a person will be filled unto all the fullness of God") further reinforces the sense that affect, love, or will, is somehow operative at this highest level of supra-intellectual cognition. For this verse speaks of "comprehending" Christ's love (caritas), which exceeds every determinate mode of being (latitudo, et longitudo, et sublimitas, et profundum) and every kind of knowledge, precisely by being filled with that love. ${ }^{138}$ This imagery of plenitude evidently agrees with the overall theory of deification in ${ }^{2} 2 \mathrm{~B}$. But by concluding on this note, Berthold leaves the reader with the impression that the deification above mind is in some sense a transformation of the human will into the divine will or charity. The soul is so filled with God that it can love itself, a creature, for God's sake. It does not require much extrapolation to construe this as the soul's participation in the divine providence. If this is so, then it is through a kind of intellect in love that the soul exercises providence with the presiding gods.

In an entry on Berthold of Moosburg in the Lexikon des Mittelalters, Willehad Eckert clearly had this passage in mind when he concluded his brief summary of the Expositio in three sentences: "[Berthold's] interest in Proclus is above all motivated by the thematic of the soul's union with God which he, according

138 Berthold of Moosburg, Expositio, 129B, p. 179, l. 197. Cf. Ephesians 3:17-19: in caritate radicati, et fundati, ut possitis comprehendere cum omnibus sanctis, quae sit latitudo, et longitudo, et sublimitas, et profundum: scire etiam supereminentem scientiae caritatem Christi, ut impleamini in omnem plenitudinem Dei ("being rooted and grounded in charity, you might comprehend with all the saints what is the breadth, length, height, and depth: to know also the charity of Christ, which exceeds all knowledge, so that you may be filled unto all the fullness of God"). 
to the model of Bernard of Clairvaux, sees as given through love". ${ }^{139}$ This is a remarkable judgement from the first scholar in the zoth century to devote substantial attention to Berthold of Moosburg. Eckert rightly marked the anthropological inspiration for Berthold's commentary, and hinted at centrality of grace to Berthold's conception of divine union (durch die Liebe gegeben sieht).

While I would agree with Loris Sturlese that a label like "affective mysticism" for Berthold's thought, which one might take Eckert's summary to imply, would be a very inadequate description of the Expositio (since, as Sturlese has put it, for Berthold "the leap into mystical experience could not be a solution" to the restrictions of the metaphysics of being), I would not go so far as to say that Berthold therefore kept Bernard's mysticism at a distance. ${ }^{140}$ It is true that Berthold only cited Bernard in two, albeit important, passages, for the doctrines of deification (129B) and contemplation $(202 \mathrm{~A})$, and, moreover, likely relied on a florilegium. ${ }^{141}$ It is also undeniable that for Berthold the Platonic alternative to the Aristotelian metaphysics of being has to be made available, in principle, to everyone who desires to follow the laborious path of reasoning according to the oblique motion of the soul, until they arrive at the unhypothetical and simple first principle that grounds all thought. So while it would be misleading to suggest, though Eckert has not, that Berthold's principal motive was to be faithful to Bernard of Clairvaux - it was to elucidate the soteriological wisdom of the Platonists - we should remain sensitive to the nuance this citation of Bernard brought to the Platonic consensus of the Expositio. When Berthold added that the unitive cognition of Proclus and Dionysius can be conceived as a transformative union of wills, we should pay attention, for it is only in such details that Berthold's understanding of the unum animae can be allowed to come into view.

It would be unsurprising if a commentator had understood providential, non-reflexive cognition through ignorance (Dionysius) or seeing the One

139 W. Eckert, "Berthold von Moosburg", in Lexikon des Mittelalters, vol. 1 (München / Zürich: Artemis, 1980), col. 2034: "Das Proklos-Interesse ist v. a. motiviert durch die Thematik der Gotteseinigung der Seele, die er nach dem Modell des Bernhard v. Clairvaux als durch die Liebe gegeben sieht".

140 Sturlese, Homo divinus, p. 152: "Daß der Sprung ins mystische Erleben für Berthold keine Lösung sein konnte, zeigt die Distanz, mit er die Mystik Bernhards in der Expositio betrachtet wird. Bernhard wird nur zweilmal erwähnt."

141 The two definitions of contemplation taken from Bernard's De consideratione in 202A have the appearance of deriving on a florilegium, but in the printed editions of the Flores Bernardi they are quite far apart: Flores sancti Bernardi, lib. v, c. 64, p. 68vb and lib. viII, c. 9o, p. 144rb; Flores operum D. Bernardi abbatis Clarevallensis, lib. v, c. 46, p. 318 and lib. VIII, c. 82, p. 622 . 
through not seeing (Proclus), in terms of love. This reading of the De mystica theologia and De divinis nominibus 7.1 had been well established since the time of Hugh of St. Victor (d. 1141) and especially Thomas Gallus (d. 1226). ${ }^{142}$ Although Berthold's citation of Bernard gestured in this direction, it is equally important to note that he nowhere made an outright identification of the activity of the soul's supra-intellectual principle with amor. Some parallels between the two notions, however, do appear elsewhere in the Expositio, where Berthold more closely associated the banquet, divine plenitude, and love. We find this connection stated most clearly in Proposition 177 ("Every intellect is a plenitude [plenitudo] of species", etc.). ${ }^{143}$ Explaining how an intellect is productive by being "subject to the superessential will" (subicitur voluntati superessentiali), Berthold linked its generative power to the presence of unity or goodness within it:

Intellect is not only receptive of species but is even profusive of itself in the specifying determination of all that is below. In this way, it makes the goodness of silence to shine forth clearly in itself - I mean the goodness which is diffusive of itself, not by reasoning or choice, which here can even be called the silence which is in the hidden places, that is, in the holies of holies. ${ }^{144}$

The fecundity of an intellect is identical with the generative "goodness of silence". The vocabulary of this passage recalls what we read in Berthold's citations of Proclus and Dionysius on the angels as "revealers of the divine silence". ${ }^{145}$ According to the exegetical possibilities made available to Berthold once he had integrated the methodology of natural and voluntary providence into Platonism, these passages about the angels can be applied proportionately

142 See D. Lawell, "Ecstasy and the Intellectual Dionysianism of Thomas Aquinas and Albert the Great", in J. McEvoy, M. Dunne, J. Hynes (eds), Thomas Aquinas. Teacher and Scholar (Dublin: Four Courts Press, 2012), p. 155-183; B.T. Coolman, Knowledge, Love, and Ecstasy in the Theology of Thomas Gallus (Oxford: Oxford University Press, 2017), p. 1-27.

143 Proclus, Elementatio theologica, prop. 177, p. 87, l. 1-5: Omnis intellectus plenitudo ens specierum, hic quidem universaliorum, hic autem particulariorum est contentivus specierum; et superiores quidem intellectus universaliorem habent quanto particulariorem qui post ipsos, inferiores autem particulariorem quanto totaliorem qui ante ipsos.

144 Berthold of Moosburg, Expositio, 177 C, p. 176, l. 116-120: Non solum autem intellectus est sic specierum receptivus, sed etiam est sui ipsius in omnium inferiorum specificationem profusivus, et sic est faciens munde resplendere in se ipso bonitatem silentii, bonitatem, inquam, sui ipsius diffusivam non ratiocinando nec praeeligendo, quod etiam potest hic vocari silentium, quod est in abditis, scilicet secretis secretorum.

145 See Expositio, Prol. 6, 26H, and 32E. 
to the activity of the gods in the domain of natural providence. ${ }^{146}$ In light of the distinction of hierarchy and antarkia in 10A, we can surmise that the difference in the proportion would be as follows: in a hierarchy ruled by will, "the goodness of silence" generates only providential operations and graces, but no substances, whereas in the order of natural providence, it is productive of entia secundum speciem by "specifying determination". Here in $177 \mathrm{C}$, Berthold connected that silence with the notions of overflow and plenitude. Although the unum is not mentioned explicitly, the language of "the hidden places" and "the holy of holies" was clearly meant to evoke the idea, found already in $162 \mathrm{~B}$, that a unitas superexaltata is at the root of each separate intellect as an ens secundum speciem. But what is most striking here was Berthold's decision to explain the word "silence", which characterised Proclus' "clearer" account of deification through the unum animae cited at $129 \mathrm{~B}$, in terms of a spontaneous and generative activity prior to reasoning or choice.

Berthold's commentary on Proposition 175 ("Every intellect is primarily participated by principles that are intellectual in both their substance and operation") had already explored the role of the will or love in the essential activity of the intelligences. ${ }^{147}$ Here, Berthold began with an argument about what belongs to the perfection of every intellectual nature in general. ${ }^{148}$ The first text he offered was Dionysius, De divinis nominibus 4.13, on "the superabundance of loving goodness" that draws God outside himself (extra se ipsum) in ecstasy (secundum extasim). Berthold maintained that this applies proportionately to every essential cause, stating that "love is an act of will, which according to its proper notion denotes what belongs to the perfection of every intellectual nature". In these intellectual substances, he explained, love does not belong to the genus of an accident because it is not related to a potency that follows the essence of the intellect or to an appetite triggered by some object outside the intellect. This was an important clarification, for it might

146 Berthold of Moosburg, Expositio, 156A, p. 169, 1. 12-21: sicut se habent superiores angeli in ordine providentiae voluntariae, ita se habent proportionaliter dii in ordine providentiae naturalis. 'Si enim', ut dicit Dionysius 4 cap. De divinis nominibus, 'enunciat bonitatem divinam boniformis' deiformis 'angelus, illud existens secundum participationem' secundo post Deum, quod quidem est secundum eam 'primo enuntiatum, imago Dei est angelus, manifestatio occulti luminis, speculum purum, clarissimum, incontaminatum, incoinquinatum, immaculatum, suscipiens totam, si est conveniens dicere, pulchritudinem boniformis deiformitatis et munde resplendere faciens in se ipso, quemadmodum possibile est, bonitatem silentii, quod est in abditis,' eodem modo proportionaliter est de diis.

147 Proclus, Elementatio theologica, prop. 175, p. 85, l. 1-2: Omnis intellectus a secundum substantiam simul et operationem intellectualibus participatur primitus.

148 Berthold of Moosburg, Expositio, 175A, p. 146, l. 13 - p. 147, l. 58. 
account for Berthold's reluctance to identify the unum animae with amor, as this could imply that it is a power somehow separate from the intellect. Rather, love is "the inclination following the apprehended form". This "will" desires its own good and communion with what is apprehended. In the case of an intellect essentially in act, this desired good is God, who is more inward to the intellect than its innermost part. In its communion with the overflowing Good, the intellect does not act by the necessity of compulsion or the necessity of nature, but by the freedom of the will, which for Berthold is entirely consistent with the immutability of necessity:149

Thus, every intellectual nature is elevated above its own nature, properly speaking, and attains to the likeness of the primarily Good. And because the will of an intellect essentially in act is not a power, but its very essence, it follows that the will does not belong to it such that the will would move once it has been moved by an external desirable object. Rather, it is said to be moved in goodness and love to cause all things that come after itself, just as Dionysius says about the primarily Good, as we saw above, that 'divine love' 'does not leave it without seed'; so too, intellectual love does not leave such an intellect barren. In this way, after the example of the primarily Good, the goodness of the will of the intellect itself cannot be without benevolence, nor can it be without the beneficence through which it communicates its goodness in every way that it can be communicated and participated by whatever things are capable of participating in whatever way. For otherwise there would be jealousy in it, since it would not diffuse or communicate the good that it can bestow without any detriment to itself - but it is known that such 'jealousy is far removed from' everything divine. ${ }^{150}$

149 Berthold of Moosburg, Expositio, 175A, p. 147, 1. 33-37: Et hoc enim duo consequuntur ipsam voluntatem, unum in se, scilicet quod bonum proprium et eius communionem desiderat et amat amore intellectuali, secundum, quod in talis boni redundantis communione non agit necessitate coactionis, sed nec proprie necessitate naturae, sed voluntatis libertate, quae bene stat cum immutabilitatis necessitate.

150 Berthold of Moosburg, Expositio, 175A, p. 147, 1. 38-50: Et sic omnis intellectualis natura elevatur supra naturam proprie dictam et accedit ad similitudinem prime boni, et quia voluntas intellectus in actu per essentiam non est potentia, sed sua essentia, patet, quod non competit ei, quod moveat mota ab appetibili extra, sed dicitur moveri in bonitate et amore ad causandum omnia, quae sunt post, sicut etiam de prime bono dicit Dionysius, ubi supra, quod 'divinus amor' 'non dimisit ipsum sine germine'; ita etiam amor intellectualis non sinit intellectum talem esse infecundum, et sic etiam ad instar prime boni bonitas voluntatis ipsius intellectus non potest esse sine benevolentia, quae etiam non potest esse sine beneficentia, per quam communicat bonitatem suam omni modo, quo communicari potest et participaria 
This is nothing if not a concise statement of Berthold's rationale for elevating "good" over "being" as the primary name of God in Propositions 1 and 7, and his understanding of "goodness" as the essential mode of any given thing, according to which an essence is intrinsically related to an order outside itself. The additional clarification here is that this communication of the good is not only an ecstasy in God and the separate substances, but that it amounts to an elevation "beyond nature" (elevatur super naturam) in all creatures below God. Through the will, an intellect that is always essentially in act goes above itself in love and beyond itself in fecundity. Similarities with the passage from ${ }_{177} \mathrm{C}$, considered above, are undeniable: through willing or love, the separate intellects "mirror" or "make present" the causality of the Good; this will is intrinsic to the essentially active intellect (in abditis) and yet transcends it (in secretis secretorum). Its activity is freedom itself, beyond reasoning or the necessity of nature, and is equivalent to "the goodness of silence" and the activity of the vestige of the One or Good in the intellect.

The echo of the Timaeus 29e in the final line of the text from $175 \mathrm{~A}$ (invidia longe ab omni divino noscitur relegata) was followed up explicitly in $175^{\mathrm{B}}$, where Berthold noted that Plato and Avicebron agreed when they stated that separate intellects "institute those things that exist by willing": Plato, when he said that "the will of God is the most certain origin of things", and Avicebron, in more precise terms, when he wrote that "Plato considered that the forms come to be in the intelligence from an intuition of the Will (ex intuitu voluntatis), and they come to be in the universal soul from an intuition of the universal intelligence". ${ }^{151}$ Berthold would have interpreted this passage from Fons vitae V.17 with reference to the highest three cosmological genera of the Elementatio theologica, but with the crucial difference that the domain of the Good has been identified with the Will. We find Berthold citing the same text whenever he wanted to explain how the separate intelligences receive the species of which they are the plenitude. ${ }^{152}$ The overall picture here suggests that the one beyond intellect, "the holy of holies" in the separate intellects wherein "the goodness of silence" reigns and is revealed in their fecundity that mirrors the Good, is

quibuscumque et qualitercumque participare valentibus. Aliter enim esset in eo invidia, cum non diffunderet et communicaret bonum, quod posset sine sui detrimento communicare, quae tamen 'invidia longe' 'ab' omni divino noscitur 'relegata.' Cf. Plato, Timaeus, $29 \mathrm{e}$.

151 Berthold of Moosburg, Expositio, 175B, p. 149, l. 109-114. On Berthold's use of Avicebron, see A. Beccarisi, "Avicebron (Solomon Ibn Gabirol) and Berthold of Moosburg on Essential Causality", forthcoming.

$15^{2}$ Berthold of Moosburg, Expositio, 145F, p. 86, l. 142 - p. 87, l. 178; 170C, p. 97, l. 103-105; 174B, p. 139, l. 89-111; 177 C, p. 173 , l. 15 and p. 175, l. 73-75. 
the "summit" of an intellectual substance that is immediately receptive to the divine will. Far from an isolated capitulation to authority, then, Berthold's citation of Bernard was an acknowledgement of how profoundly the abbot's notion of deification - a transformative plenitude arising from union with the divine will - agreed with what Berthold found in the Timaeus (the divine will, free from jealousy, as the origin of all things), the Phaedrus (on the feast in the heavenly circuit, reported by Proclus), Dionysius (the ecstatic love of the Good), and Proclus (the silent "frenzy" and union with the divine providence).

For Berthold, the simplicity of an intellectual substance was primary, and the notion of will or love could not compromise it. ${ }^{153}$ The idea that the vestigium unius in all spiritual substances could be realised through a kind of love is, however, consistent with our earlier analysis of the unum animae and acquired intellect, where we concluded that the former should be seen as the higher phase of the latter, the kernel of non-reflexivity that grounds all intellectual activity. To the extent he has identified love with this higher phase, Berthold seems to have reached for the same doctrine expressed succinctly by Plotinus (d. 270):

So, Intellect has one power to think insofar as it regards what is in itself, and another insofar as it regards what transcends itself, with a kind of apprehension and receptivity. It is in accordance with the second power that it first sees, and then later while still seeing both comes to be intellect and a unity. And the former is the contemplation of a wise intellect, whereas the latter is intellect loving, when it becomes senseless, 'drunk with nectar'; then it falls in love, simplified into happiness by having its fill. And it is better for it to be drunk with this drunkenness than to be sober. ${ }^{154}$

For Plotinus as for Berthold, it would be inappropriate to speak of love as something separate from intellect. The drunkenness of intellect is rather one mode or "power" of its seeing that is always concomitant with the "sober" and reflexive knowing that it grounds: "intellect always has its thinking and always its non-thinking", as Plotinus went on to explain. So too for Berthold, not only is the agent intellect of the soul always active, as Dietrich had argued, but the unum animae must be even more active than it. Even if their operations belong to the whole soul only accidentally, it is clear for Berthold that both are given to

\footnotetext{
153 Cf. Berthold of Moosburg, Expositio, 175B, p. 15o, l. 120-129.

154 Plotinus, Enneades, Vi.7[38].35. English translation: Plotinus, The Enneads, ed. L. Gerson (Cambridge: Cambridge University Press, 2018), p. 842 (modified).
} 
the soul as a pair. But what Plotinus made explicit, and which Berthold, without knowing the Enneads, assumed in his endorsement of Avicebron's summary of Plato's explanation of how forms come to be in the intellect (ex intuitu voluntatis; subicitur voluntati superessentiali), was that the ecstatic activity of intellect in love, its "reaching out" ( $(\pi / \beta \circ \lambda \eta \dot{)})$, is simultaneously a "receptivity" $\left(\pi \alpha \rho \alpha \delta 0 \times \eta^{\prime}\right) .{ }^{155}$ Berthold would have encountered the transliteration of the first term in Moerbeke's translation of the De providentia et fato (epibolis, id est adiectionibus, simplicibus), but for him this passage in Proclus referred to the higher phase of the possible intellect as it intuits and receives simple formal intentions from the agent intellect. ${ }^{156}$ Be that as it may, we have now seen that the same dynamic of higher and lower modalities is found at the next and highest level, where the agent intellect, having been united to the possible intellect in its lower phase, intuits, receives, and constitutes forms immediately from the divine will in its higher phase.

Far from undermining the philosophical coherence of the Expositio, the notion of the unum animae as a kind of affective intellect can bring some much-needed clarity to Berthold's occasionally faltering attempts to define the proper activity of the unum apart from the intellectus agens. ${ }^{157}$ This struggle is nowhere more apparent than in the commentary on Proposition 124 ("Every god knows the divisible indivisibly, the temporal atemporally, the contingent necessarily, the changeable unchangeably, and in general all things more eminently than they are in their own order"). ${ }^{158}$ After explicitly referring back to the degrees of cognition outlined in $123 \mathrm{D}$, Berthold declared that it would suffice to collapse the highest two modes (the fifth: intellectus adeptus and unum animae; the sixth: the cognition of the separate intelligences) into one, called "the intellective". 159 Following Dietrich of Freiberg, he maintained that the intellective embraces the lower forms of sensitive and rational cognition

155 On the influence of this doctrine on Dionysius, see M. Harrington, "The Drunken Epibole of Plotinus and its Reappearance in the Work of Dionysius the Areopagite", in Dionysius 23(2005), p. 117-138.

156 Berthold of Moosburg, Expositio, 123D, p. 129, l. 144-147.

157 Proclus, De decem dubitationibus circa providentiam, q. 1, §5, p. 8, 1. 4-6: necesse et providentialem cognitionem super intellectualem esse, et sic utique omnia providentiam cognoscere uno quod sui ipsius, secundum quod et bonificat omnia [...].

${ }_{15} 8$ Proclus, Elementatio theologica, prop. 124, p. 62, 1. 1-4: Omnis deus impartibiliter quidem partibilia cognoscit, intemporaliter autem temporalia, non necessaria autem necessarie et transmutabilia intransmutabiliter, et universaliter omnia eminentius quam secundum ipsorum ordinem.

159 Berthold of Moosburg, Expositio, 124A, p. 139, l. 15 - p. 140, 64. Cf. Dietrich of Freiberg, Quaestio utrum in Deo sit aliqua vis cognitiva inferior intellectu, 1.1.5-10, p. 294, 1. 34 p. 295, 1.67. 
within itself in a simple mode (in ipso uniuntur modo simplici). This is because the intellective knows an object in the simple essence (simplex essentia) that is intrinsic to the intellect itself: unlike the sensitive power, which is occupied with the particular, and reason, which abstracts the universal, the cognition of the simple essence is neither universal nor particular (nec est universalis nec particularis / nec est individua nec universalis proprie loquendo). That is, the agent intellect contains the essence it knows and produces within itself, and does so in a simpler and nobler way than the essence exists in its effect or in the possible intellect, which apprehends it only through its divided formal parts. Such a cognition beyond the universal and particular was precisely what Proclus intended to convey with his notion of divine providence as what is prior to intellect. ${ }^{160}$ Berthold explicitly acknowledged this in $124 \mathrm{~B}$, but was confined to making a fortiori arguments about the unum animae as a cognitive principle based on Dietrich's descriptions of the intellectus in actu per essentiam. ${ }^{161}$ Compared with these rather awkward and ambiguous passages, the clarity of Berthold's proposal that the separate intellects are "elevated above nature" by their will that is identical with their essence $\left(175^{A}-B\right)$ is more informative. Not the cognition of the separate intellects but their fecundity is related to the vestige of the One within them, in which they are always located (illocantur) and, for that reason, always "imitate the gods". 162

Providence is found wherever there is an active vestige of the One. ${ }^{163}$ This providence is operative in the human soul, even when a person is not aware of it, through the unum animae, which is the principle of order and harmony among the parts. As such, the unum animae (or, perhaps better here, the bonum animae) is nothing else than the origin of divine love in the soul. ${ }^{164}$ In this

160 Proclus, Elementatio theologica, prop. 120, p. 6o, l. 10-11: Et enim ubi que pronoy (id est intellectus provisoris) operatio nisi in supersubstantialibus? See also the parallel text to Proposition 124 in Proclus, De decem dubitationibus circa providentiam, q. 1, §5, and especially at p. 8, 1. 8-11: Non enim est le unum ipsius velut le individuum unum: hoc enim ultimum entium et universali deterius, quo participans est quod est, illud autem et universali melius [...].

161 Berthold of Moosburg, Expositio, 124B, p. 141, l. 78-85; 124C, p. 141, l. 99-100; 124D, p. 143, l. 152-154 and 170-172. See also Expositio, 83B, p. 125, l. 88 - p. 126, l. 108 on the higher "certitude" of the superintellective.

162 Berthold of Moosburg, Expositio, 134F, p. 217, l. 106-132.

163 Berthold of Moosburg, Expositio, 120H, p. 102, 1. 382-383: ubicumque invenitur unum secundum actum, ibi et providere invenietur.

164 Berthold of Moosburg, Expositio, 141F, p. 5o, 1. 194 - p. 51, l. 197: immo etiam supremum intra eandem essentiam sive substantiam respectu residuae portionis, sicut apparebit in anima, habet providentiam coordinatam propter alternam habitudinem eorum ad invicem, quam efficit divinus amor in eis. At Expositio, $141 \mathrm{D}$, p. 48, l. 122 - p. 49, l. 143, this is directly related to the exstasis divini amoris. 
sense, the unum as the highest term within its own "order" must be placed prior by nature to the agent intellect as the essential principle or auxiliary cause of the soul for exactly the same reason Berthold placed the Good prior to being: it provides the holistic field of possibility in which the intellect will operate. On this question Berthold had invoked Avicebron's notion of the divine will in the Fons vitae as the power that creates and sustains the union of matter and form by ordering the parts in relation to one another and to their source. ${ }^{165} \mathrm{By}$ "intuiting" this will, an intellect becomes a plenitude. Like the caritas of Ephesians 3:19, this providential will is only "comprehended" when one is filled with it. ${ }^{166}$ In this way it surpasses the determinate knowledge of the intellect. When the soul is "located" in its ground, even if only for a moment, it shares in the unitive knowledge of the higher principles - but there is also something more:

Their providence consists not in conjectural reasonings about the future, as in the case in political affairs among us; but by taking their station in the animative one, and through this being illumined all about with the unifical light of the gods, they see things in time atemporally, and divided things indivisibly, and those things in place without any place, and they do not belong to themselves, but to those illuminating them. ${ }^{167}$

Passages like this indicate why Berthold would interpolate Proclus into the description of the astronomer's knowledge and activity in the Prologue, for this

165 Berthold of Moosburg, Expositio, 13D, p. 215, l. 201-218, citing Avicebron, Fons vitae, lib. v, c. 31, p. 315, l. 5-21 and lib. v, c. 36, p. 323, 1. 17-20: 'Fac me scire, quod est ligans materiam et formam, et quid est uniens et retinens earum unitionem, et quid est', respondetur ex persona magistri: 'Haec est voluntas, quae est suprior illis, quia unitio formae et materiae non est nisi ex impressione unitatis in illis. Et postquam inter unum et duo non est medium, scias per hoc, quod inter unitatem et materiam et formam non est medium. Discipulus: Quod est signum, quia unitas ordinatrix est materiae et formae? Magister: Signum ad hoc est omnimoda unitio materiae et formae firma et stabilis et perpetua in earum creatione, id est principio unitionis [...].' Et hoc est, quod dicit ibidem 36 cap.: 'Verbum, scilicet voluntas, postquam creavit materiam et formam, ligavit se cum illis, sicut est ligatio animae cum corpore, et effudit se in illis et non discessit ab eis et penetravit a summo usque ad infimum. Shortly before this, at ${ }_{13}$ C, p. 214, l. 169-197, Berthold had cited passages from Dionysius on the Good as the cause of friendship (amicitia) among the orders of beings.

166 See n. 138 , above.

167 Berthold of Moosburg, Expositio, 134F, p. 217, l. 127-132, citing Proclus, De decem dubitationibus circa providentiam, q. 10, §64, p. 106, 1. 13-18: et ipsorum providentia non in rationalibus coniecturativis futurorum, sicut politicorum, qui hic, sed in uno animeali stationem sumens; et per hoc circumlustrare uniali lumine deorum vident akhronos, scilicet intemporaliter, quae in tempore, et indivisibiliter divisa, et quae in loco omnia sine loco, et sunt non sui ipsarum, sed illustrantium. 
is nothing else than a description of a prophetic knowledge whose certainty exceeds any prediction confined to the realm of becoming. ${ }^{168}$ Everything in this description could apply to the cognition of an intellectus in actu per essentiam or, on the human level, the acquired intellect (i.e., the "intellective" of $124 \mathrm{~A}$ ) - except for the final clause stating that the soul no longer belongs to itself, as it would in reflexive, essential cognition, but to the higher causes. This we may connect with the love that elevates intellect beyond its nature to imitate the divine generative providence, by which it manifests "the goodness of silence", which has for its spontaneous result the perfect communication of illumination to those that are below. ${ }^{169}$

Berthold's synthesis of the Clavis physicae, Proclus, and Dietrich of Freiberg in his exemplarist anthropology, and his views about its perpetual providential activity to which the individual is related through the unum animae, bear striking similarities to Meister Eckhart's speculations about the relation of the individual to human nature and what this relation entails for the ethical life and the exercise of charity. Eckhart's understanding of the patristic adage that the purpose or "fruit" of the Incarnation was "that man may become by the grace of adoption what the Son is by nature" was closely related to his interpretation of 2 Corinthians 3:18: the adopted sons of God will be changed into the "same" image (in eandem imaginem transformamur) as the only-begotten Son. ${ }^{170}$ Shortly after the passage discussed earlier, where Eckhart denied that beatitude would consist primarily in a reflexive act of the intellect, he stressed that the Word is received only by those who are "empty of every form impressed or begotten by creatures". ${ }^{171}$ Eckhart applied this principle again when commenting on the wedding at Cana and "the marriage" of human and divine natures, and went further to unfold the ethical demand this natural philosophical principle places on the individual. ${ }^{172}$ Since the Word assumed human nature, not a human person - and since human nature is univocally common to all, including Christ, and is more interior to every person than they are to themselves - it follows that whoever "wishes to become son of God [...] must love

\footnotetext{
168 See 1.2, n. 66, above.

169 Berthold of Moosburg, Expositio, 153F, p. 155, l. 231-242.

170 Meister Eckhart, Expositio sancti evangelii secundum Iohannem, §106 (John 1:12-13), p. 9o, l. 11 - p. 91, l. 2. Cf. 2 Corinthians 3:18: Nos vero omnes, revelata facie gloriam Domini speculantes, in eamdem imaginem transformamur a claritate in claritatem, tamquam a Domini Spiritu.

171 Meister Eckhart, Expositio sancti evangelii secundum Iohannem, §110 (John 1:12-13), p. 94, 1. 13-14.

172 Meister Eckhart, Expositio sancti evangelii secundum Iohannem, §289-291 (John 2:1), p. 241, l. 5 - p. 244, l.4.
} 
their neighbour as himself" and must deny whatever is personal and one's own (abnegare personale, abnegare proprium). This, Eckhart stated, is charity: to love one God in all things and all things in him (diligit siquidem unum deum in omnibus et omnia in ipso).

He advanced this metaphysical and ethical teaching even more strongly in his sermons. Here are two especially clear examples:

The masters say that human nature has nothing to do with time, that it is entirely untouchable and much more intimate and closer to man than man to himself. And, therefore, God took on Himself human nature and united it with His persons. There, human nature became God, because He took the naked human nature itself on and not a man himself. Therefore, if you wish to be the same Christ and be God, so abandon everything that the eternal Word did not assume. The eternal Word did not take on Himself a human being, hence, abandon what is a human being in you and what you are, and take yourself according to naked human nature, then you are the same with the eternal Word which human nature is with Him. As there is no difference between your human nature and His own, it is one, because what it is in Christ, this it is in you. ${ }^{173}$

The eternal Word did not take this person or that person to itself, but it took a free and undivided human nature to itself, which was naked without image; because the simple form of humanity is without image. And, therefore, as in this assumption human nature was assumed by the eternal Word as a simple one without image, the image of the Father, who is the eternal Son, became the image of human nature. Because as sure as God became man, so true it is that man has become God. And so human nature has been overformed by having become the image of God, who is the image of the Father. And so, if you shall be one Son, you need to detach yourself and leave everything that makes a distinction in you. Because man is an accident of nature; and, therefore, leave aside all that is an accident in you, and take yourself according to the free and undivided human nature. And since the same nature, according to which

173 Meister Eckhart, Predigt 24 (First Sunday in Advent), ed. J. Quint, Die deutschen Werke, vol. 1 (Stuttgart: Kohlhammer, 1958-1986), p. 420, l. 2-11. English translation: Meister Eckhart, The German Works. 64 Homilies for the Liturgical Year. 1. De tempore, eds L. Sturlese, M. Vinzent (Leuven: Peeters, 2019), p. 89. See also the Latin sermon on the same pericope: Meister Eckhart, Sermo LII (First Sunday in Advent), §523, p. 437, l. 7 - p. 438, l. 5. Cf. Meister Eckhart, Predigt 25 (Tuesday after Fourth Sunday in Lent), ed. J. Quint, Die deutschen Werke, vol. 2 (Stuttgart: Kohlhammer, 1971-1988), p. 13, l. 14- p. 16, l. 3. 
you will take yourself, has become the Son of the eternal Father by the assumption of the eternal Word, so you will become with Christ the Son of the eternal Father, because you take yourself according to the same nature that there has become God. ${ }^{174}$

Eckhart would later defend these ideas in the proceedings of his trial in Cologne, appealing to the same arguments we find in his commentary on John about the purpose of the Incarnation, the distinction between the onlybegotten Son by nature and the sons by adoption through grace, and its implications for the correct understanding of charity as leaving off "this" or "that". 175 While these portions from the proceedings did not ultimately factor into the papal bull In agro dominico (1329), two articles deriving from passages closely related to them were censured, which taken on their own might imply a kind of naturalistic autotheism (article 11: whatever the only-begotten Son has in his human nature, "he gave all this to me") or the loss of any distinction between the only-begotten Son and the sons of God by adoption (article 12: whatever the Scriptures say of Christ, all of this is true of every divine person). ${ }^{176}$

While the Incarnation was of course methodologically excluded from Berthold's consideration of the Elementatio theologica, it is nevertheless quite conceivable that his view of the relation of an individual within the order of voluntary providence (Eckhart: "leave aside all that is accidental in you") to human nature as an ens secundum speciem (Eckhart: "human nature has nothing to do with time") which exercises providence with the gods (Eckhart: "assumed by the eternal Word") through the unum animae (Eckhart: "it is entirely untouchable and much more intimate and closer to man than man to himself"), would have direct consequences for any treatment of the subject. Berthold's theory of the double descent of the soul, preserved a subtle but clear distinction between the individual and human nature. The theory of deification he outlined in Proposition 129 affirmed that the individual "lives by the divine life" through the unum animae, but also made it explicit that this transformation

174 Meister Eckhart, Predigt 46 (Eve of the Ascension), ed. J. Quint, p. 379, l. 6 - p. 382, l. 3. English translation: Meister Eckhart, The German Works. De tempore, p. 591-593.

175 Meister Eckhart, Magistri Echardi Responsio ad articulos sibi impositos II, ed. L. Sturlese, Acta Echardiana, Die lateinischen Werke, vol. 5 (Stuttgart: Kohlhammer, 2006), §65-72, p. 333, l. 8 - p. 336, l. 14 .

176 In agro dominico, ed. L. Sturlese, Acta Echardiana, p. 598, 1. 47-51: Undecimus articulus: Quicquid deus pater dedit filio suo unigenito in humana natura, hoc totum dedit michi. Hic nichil excipio, nec unionem nec sanctitatem. Sed totum dedit michi sicut sibi. Duodecimus articulus: Quicquid dicit sacra scriptura de Christo, hoc etiam totum verificatur de omni bono et divino homine. 
was not the annihilation of individuality (the Clavis physicae) or the individual will (Bernard of Clairvaux). It is rather the harmonisation of the individual to their own nature and, through that nature, to the divine. The union, as the citation of Bernard especially affirmed, is to be "one in spirit" with God through the union of wills. Nevertheless, Berthold's attempt to offer a metaphysics of deification through a theory of human nature clearly moved along the trail that Eckhart had opened.

Berthold was not alone among his contemporaries in developing these Eckhartian themes. In his defence of Eckhart's orthodoxy in the Little Book of Truth (c. 1330), Henry Suso took great care to nuance the master's thought on these questions of the Incarnation, human nature, and individuality or personhood, with arguments from the Summa theologiae of Thomas Aquinas. ${ }^{177}$ In one of the few sermons preserved from Berthold's confrere in Bavaria, Henry of Ekkewint, we find the Dominican preaching about the spark or tiny flame in the soul (derfunke oder der glanster der sêle). This spark has a perpetual apprehension of the divine reasons and guides a person with ethical council. Its constant advice is that "you should let go of all man, so that you may be free of him, as if all of human nature was enclosed within you and your nature was the essence of all people, and as if you could see yourself in every man and every man in you". 178 Berthold could be seen as combining the Eckhartian speculation about the ontological status of human nature with the approach we find in Henry of Ekkewint that focuses on a principle in the soul that mediates the relation of an individual to human nature, and guides a person in charity.

Of all Berthold's contemporaries, however, John Tauler came the closest to what we find in the Expositio. In a sermon preached on the Nativity of John the Baptist, Tauler surveyed the various ways the faculties and powers in the soul "bear witness to the light" (John 1:7-8). ${ }^{179}$ The lower faculties, the concupiscible and irascible, give one kind of testimony, by turning away from appetites and through perseverance. The higher powers of reason, will, and love, bear witness by apprehending the mysteries of God from afar, as John the Baptist had insofar as he was a prophet. But even this apprehension is separated from the light by a veil; the higher powers cannot attain to the ground (grunt). Here which, Tauler stressed, is in fact no "here" at all, because it is prior to "this" or "that" - no image, determinacy, or created light can enter. Perhaps because the language of "ground" could imply a kind of stasis or sterility, Tauler switched

\footnotetext{
177 See F. Retucci, "On a Dangerous Trail. Henry Suso and the Condemnations of Meister Eckhart", in J. Hackett (ed.), A Companion to Meister Eckhart, p. 587-6o5, at p. 595-599.

178 See Introduction, section 1, n. 29, above.

179 John Tauler, Predigt 61 (Nativity of John the Baptist), p. 329, l. 33 - p. 332, l. 19.
} 
to the semantic register of the abyss (abgrunt) and to imagery of the churning ebb and flow of the sea. Here we may recall for Berthold how the unum animae is both silence and frenzy and is a more active principle than anything encountered in the world of experience. When the soul is engulfed in this abyss, Tauler continued, it finds God's eternal dwelling-place, which God has never left. Here, eternity is experienced and tasted, where there is no past and no future. Tauler's preference for the term "abyss" also allowed him to establish a dynamic relation of difference and identity between the soul and God through the image of one abyss calling out to another (Psalm 41:8: abyssus abyssum invocat ) - just as, for Berthold, the Good summons all of its vestiges back to itself. ${ }^{180}$ Whoever becomes aware (war neme) of this calling finds that a light projects out from the ground and directs all the faculties of the soul toward their principle and origin: this is the voice, like John the Baptist, calling the soul out into the desert. When the soul enters this wilderness, which is beyond all thought, speculation, space, and time, it "is simple and without distinction". The "experience" of God here is, one might say, the experience of remaining, where a person finds human nature as it always was:

And to the one who truly enters here, it seems as though he has been here eternally and as if he were one with him, even though this endures for only a blink of an eye, and these blinks feel and appear as though they last an eternity. And this radiates a light to the outside, and testifies that the human was eternally in God in his uncreatedness. When he was in him, then the human was God in God. ${ }^{181}$

Just as with Berthold, the soul's entry into its ground coincides with an encounter with the exemplar of human nature in God, outside of the realm of becoming and change. And so, Tauler concluded, unless a person returns to that state of purity that was theirs when they passed from their uncreated to their created state, they will never return to God. ${ }^{182}$ This not only requires forsaking

180 Berthold of Moosburg, Expositio, 7 B, p. 146, l. 270-282.

181 John Tauler, Predigt 61 (Nativity of John the Baptist), p. 331, 1. 26-31: Es ist einvaltig und sunder underscheit, und wer her in geratet recht, dem ist als er alhie eweklich gewesen si und als er ein mit dem selben si, noch denne das es nút enist denne ougenblike, und die selben blicke die vindent sich und zoeigent sich ein ewigkeit; dis lúchtet es us und git ein gezúg das das der mensche was eweklichen in Gotte in siner ungeschaffenheit. Do er in im was, do was der mensche Got in Gotte.

182 Cf. Meister Eckhart, Predigt52 (Martyr), ed.J. Quint, Die deutschen Werke, vol. 2, p. 491, l. 9 p. 494, l. 3. English translation: Meister Eckhart, The Essential Sermons, Commentaries, Treatises, and Defense, p. 200. 
attachment and possessiveness. The spirit must also be transformed with the light of grace and must make itself habitually acquainted with its own inwardness. Given this background, it is all the more remarkable that Tauler immediately introduced Proclus alongside Plato and other unnamed pagans who "were familiar with this ground". ${ }^{183}$ Proclus had also featured at the conclusion of Tauler's sermon on Holy Cross Day after a similar exemplarist account of the soul's ground. ${ }^{184}$ As in his sermon for Trinity Sunday, Tauler was not interested in disabusing his audience of the impression that Proclus and Plato were therefore familiar with the state of simplicity he has just described. ${ }^{185} \mathrm{He}$ was more concerned with making the point that these pagans were more familiar with the hidden dignity of human nature, made known to them through a kind of grace of which they were fully aware, than the Christians of his own day. If we want to imagine the ethical implications and cultural context of Berthold's investigation of the invisible things of God in the order of natural providence, and his conclusions about the activity of the unum animae as a kind of providential love that never deviates from its non-reflexive directedness toward its source, we need look no further. ${ }^{186}$

183 On this passage, see Part 1, n. 6 and 3.2, n. 82, above.

184 John Tauler, Predigt 65 (Holy Cross), ed. F. Vetter, p. 358, 1. 10-16: In der verborgenheit wirt der geschaffen geist wider getragen in sin ungeschaffenheit, do er eweklichen gewesen ist e er geschaffen wúrde, und bekent sich Got in Gotte und doch an im selber creatur und geschaffen. Aber in Gotte sint alle ding Got, do sich diser grunt inne vindet. 'Als der mensche her in kumt', spricht Proculus, 'was denne uf den usseren menschen gevallen mag: armuete, liden oder gebreste, das si weler kúnne es si, des enachtet der mensche nút.' ("In this hiddenness, the created spirit is drawn back into its uncreatedness, where it is existing eternally before it was created, and it knows itself God in God, but acknowledges itself to be a creature and created. But in God all things are God, where this ground finds them within. 'When a person enters here,' says Proclus, 'whatever then happens to the outer person - poverty, suffering, failure, whatever these kind these might be - the person does not notice it' ".).

185 See 3.2, n. 81, above.

186 See also John Tauler on "essential prayer", in Predigt 24 (Sunday after the Ascension), ed. F. Vetter, p. 101, 1. 22 - p. 102, 1. 29, and on the mystical body, in Predigt 39 (Fifth Sunday after Trinity), p. 158, l. 1 - p. 159, l. 22. 